\title{
Ethnomedicinal Plants Traditionally Used for the Treatment of Jaundice (Icterus) in Himachal Pradesh in Western Himalaya-A Review
}

\author{
Disha Raghuvanshi ${ }^{1}$, Rajni Dhalaria ${ }^{1} \mathbb{D}$, Anjali Sharma ${ }^{1}$, Dinesh Kumar ${ }^{2} \mathbb{D}, \operatorname{Harsh}_{\text {Kumar }}{ }^{2} \mathbb{D}$, Martin Valis $^{3}$, \\ Kamil Kuča ${ }^{4,5, *(D)}$, Rachna Verma ${ }^{1, *(D)}$ and Sunil Puri ${ }^{1}$
}

1 School of Biological and Environmental Sciences, Shoolini University of Biotechnology and Management Sciences, Solan 173229, India; disha.raghuvanshi786@gmail.com (D.R.); rajnidhalaria86@gmail.com (R.D.); anjalisharmaas8749347@gmail.com (A.S.); spuri56@yahoo.com (S.P.)

2 School of Bioengineering and Food Technology, Shoolini University of Biotechnology and Management Sciences, Solan 173229, India; dkchatanta@gmail.com (D.K.); microharshs@gmail.com (H.K.)

3 Department of Neurology of the Medical Faculty of Charles University and University Hospital in Hradec Kralove, Sokolska 581, 50005 Hradec Kralove, Czech Republic; martin.valis@fnhk.cz

4 Department of Chemistry, Faculty of Science, University of Hradec Kralove, 50003 Hradec Kralove, Czech Republic

5 Biomedical Research Center, University Hospital in Hradec Kralove, Sokolska 581, 50005 Hradec Kralove, Czech Republic

* Correspondence: kamil.kuca@uhk.cz (K.K.); rachnac83@gmail.com (R.V.); Tel.: +420-603-289-166 (K.K.)

check for updates

Citation: Raghuvanshi, D.; Dhalaria, R.; Sharma, A.; Kumar, D.; Kumar, H.; Valis, M.; Kuča, K.; Verma, R.; Puri, S. Ethnomedicinal Plants Traditionally Used for the Treatment of Jaundice (Icterus) in Himachal Pradesh in Western Himalaya-A Review. Plants 2021, 10, 232. https://doi.org/ $10.3390 /$ plants 10020232

Received: 8 November 2020

Accepted: 20 January 2021

Published: 25 January 2021

Publisher's Note: MDPI stays neutral with regard to jurisdictional claims in published maps and institutional affiliations.

Copyright: (c) 2021 by the authors. Licensee MDPI, Basel, Switzerland. This article is an open access article distributed under the terms and conditions of the Creative Commons Attribution (CC BY) license (https:/ / creativecommons.org/licenses/by/ $4.0 /)$.

\begin{abstract}
Ethnomedicinal plants have a significant role in the lives of people of rural and tribal areas. Thousands of medicinal plant species are used to treat various diseases, including jaundice, and are considered an important therapeutic resource to minimize these diseases. Jaundice (icterus) is a chronic disease that occurs when the amount of bilirubin in the blood increases. This review describes different ethnomedicinal plants used for curing jaundice by tribal and rural people of Himachal Pradesh. The study reveals 87 ethnomedicinal plant species belonging to 51 different families, which are used for treating jaundice in Himachal Pradesh. These plants are arranged in a systematic way, which includes a description of their common name, botanical name, along with its family, plant parts used, region, and mode of use in tabulated form. Some of the plant extracts have already been explored for their phytochemical and pharmacological significance and proved their potential in the preparation of new medicines or drugs against the treatment of jaundice. This review is an attempt to highlight the indigenous knowledge of medicinal plants, which are specifically used for the treatment of jaundice. The data mentioned in the present review is compiled from various sources like existing literature, books, Google Scholar, and Scopus publications. Among all the observed plant species, most used medicinal plants for the treatment of jaundice include Justicia adhatoda, Emblica officinalis, Ricinus communis, Saccharum officinarum, Terminalia chebula, Berberis aristata, Cuscuta reflexa, and Tinospora cordifolia. Plants that are mostly utilized for the treatment of jaundice need to be scientifically validated by pharmacological analysis and should be subsequently used for the preparation of new drugs, which may prove far more beneficial than the existing one.
\end{abstract}

Keywords: jaundice; bilirubin; ethnomedicinal plants; phytoconstituents; hepatoprotective

\section{Introduction}

Himachal Pradesh is one of the Himalayan states of India, which has been regarded as the richest resource of biodiversity. The area is rich in medicinal plants, which are widely used by the people of different tribal and rural areas. The state is divided into 12 districts and 169 tehsils and sub-tehsils, covering a total area of $55,673 \mathrm{~km}^{2}$ with altitude variation from 200-7000 m above sea level [1]. Geographically, the state shows three different zones or regions, known as the outer Himalaya, mid-hills, and the greater Himalaya. The outer 
Himalaya, also known as the Shiwalik hills, ranges from $350 \mathrm{~m}$ to $1500 \mathrm{~m}$ above sea level and includes districts, such as Bilaspur, Sirmour, Kangra, Una, Chamba, Mandi, Hamirpur, and some parts of Solan. Mid-hills (1500 to $3500 \mathrm{~m}$ above sea level) cover the area of Mandi, Kangra, Chamba, Solan, Shimla, Lahaul-Spiti, Kinnaur, and Kullu districts. The Greater Himalaya (ranges 3500 and above) covers the area of Lahaul-Spiti, Kullu, and Pangi tehsil of Chamba district, which is also known as the high-altitude alpine area [2,3]. Himachal Pradesh in the lap of western Himalaya is well-known for its floral diversity, including medicinal plants, which are used since ancient times for the treatment of jaundice. The dependency of human beings on plants is an age-old relationship, which is described as 'ethnobotany'. Ethnobotany comes from the term ethnology, which means the study of culture, so ethnobotany or ethnobiology is a scientific study of plants and human relationship, which shows plants as a primary source of need. Ethnobotany deals with various aspects in which one of the most popular and common aspect is the study and use of ethnomedicines. Ethnomedicine involves the study of indigenous beliefs, concepts, knowledge, and practices among the ethnic groups of tribal and rural people for preventing, curing, and treating jaundice. For human existence, since ancient times, especially, the ethnic or tribal community has a great dependence on local flora for medicinal and other purposes [1,4]. The traditional medicine system represents the indigenous beliefs, skills, and practices of rural and tribal communities based on their experiences to maintain their health [5]. Traditional medicines play an efficient role in the preparation of herbal drugs for the betterment of people [6]. This system of medicines is used for curing diseases through the employment of agencies and forces of nature. Tribal people have their own system of medicines, which are age-old, and some of which are not documented in the literature. This tradition has been passed on from one generation to the other for treating jaundice. The information on medicinal and various other plants comes from the ancient people when they started learning and making use of these traditional plants for various purposes [7,8].

Medicinal plants are regarded as the gift of nature to humans. Various parts of medicinal plants, including herbs, shrubs, and trees, are used for curing jaundice and diseases like neurodegenerative, inflammatory, anthelmintic, diaphoretic, diuretic, etc. According to WHO (World Health Organization), "medicinal plant is a plant, within which one or more of its part contains the substances, which can be further used for various therapeutic purposes, and serves as a precursor for chemo-pharmaceutical semi-synthesis" [9]. Various bioactive compounds of plants called the secondary metabolites are the reason for their medicinal value and include glycosides, tannins, steroids, alkaloids, terpenoids, essential oils, etc. [10]. Himachal Pradesh is endowed with a rich diversity of plants, which includes 3500 higher plants, and of these, 1500 plants are identified with medicinal and aromatic properties [11]. Because of the geographical position and difficult means of transport and communication, people of some major tribes of Himachal Pradesh (Gaddi, Gujjar, Kinnaura, Lahula, and Pangwals) mostly live in villages and rural areas and belongs to diverse cultures. These people, with their specific traditional knowledge, make use of different medicinal plants for curing jaundice [1]. Medicinal and ethnobotanical uses of different plant species are documented by various researchers or scientists from different areas of Himachal Pradesh based upon the information provided by the local ethnic people [12]. Ethnomedicines have made good contributions in the health care system in traditional medicines for the treatment of jaundice since ancient times. There are two broad categories for the use of medicinal plants; firstly, plants are used traditionally only by local physicians for getting relief from illness, and secondly, the plants are used by pharmaceutical companies for their active ingredients [13]. According to WHO, due to poverty and lack of modern medicines among different rural and tribal areas, it is estimated that about $70-80 \%$ of the world's total population is totally dependent on the local medicinal plants for their primary healthcare system [8].

Ethnomedicinal plants are generally used for curing various ailments like diabetes, dysentery, typhoid, and jaundice. Different parts of the plant, including roots, leaves, fruits, and flowers, are used for the treatment of jaundice. Furthermore, jaundice is not just a 
disease rather a sign of a disease that occurs in the liver, which indicates impairment of the liver functioning [14,15]. The foremost ancient literature says that "iecur" is a Latin word that was previously used to describe the term liver [16]. Basically, the term jaundice is taken from the french word "jaune", which means "yellowness" and is characterized by yellow pigmentation [17]. Pigmentation is generally shown by the skin and eyes. It occurs due to the exceeding level of bilirubin. Bilirubin is synthesized in the body and is a natural product that is produced because of hemolysis through the action of liver cells, which further in the presence of biliverdin reductase leads to the production of bilirubin or unconjugated bilirubin. The metabolism of bilirubin describes the pathophysiology of jaundice, as shown in Figure 1.

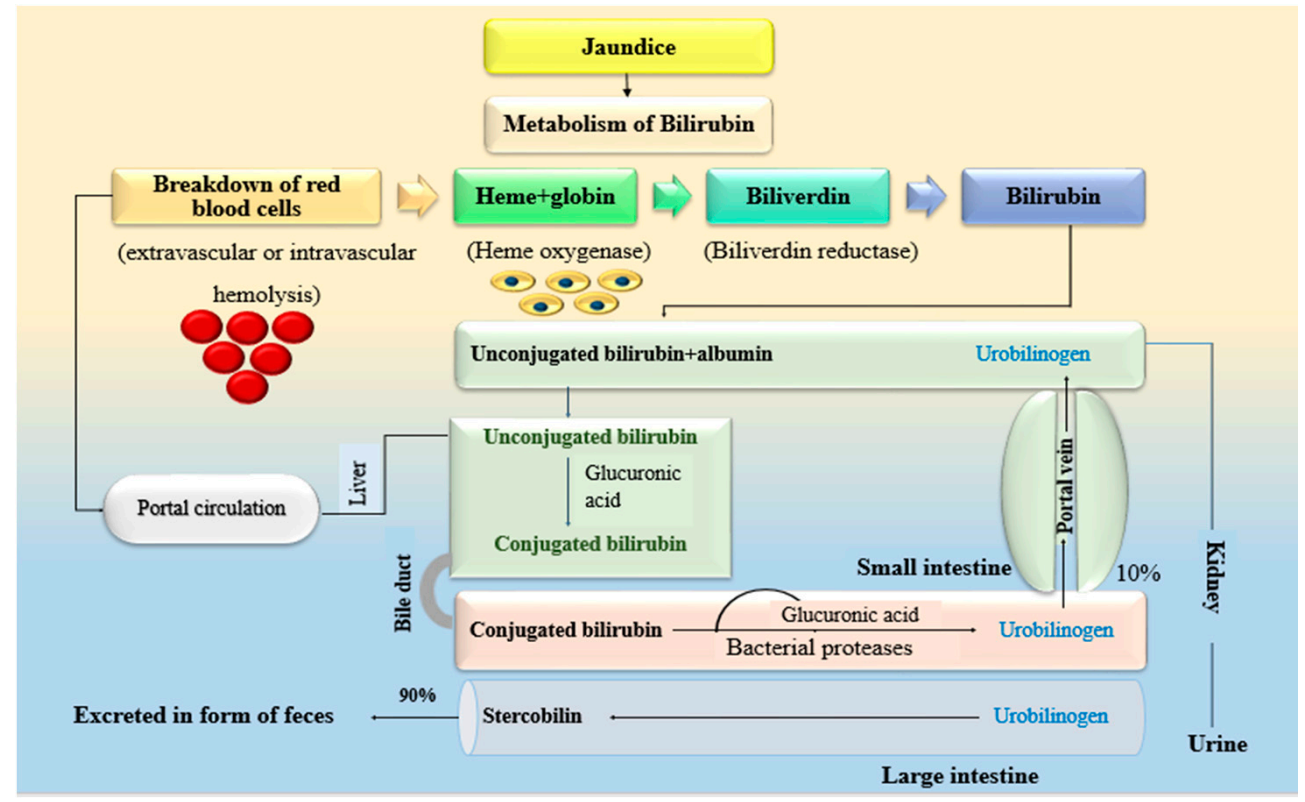

Figure 1. Bilirubin metabolism or pathophysiology of jaundice [15].

Under normal circumstances, unconjugated bilirubin (lipid-soluble) in the presence of glucuronic acid gets converted into conjugated bilirubin (water-soluble), which is released in the small intestine. Removal of glucuronic acid in the presence of bacterial protease takes place in the small intestine, which further passes through the large intestine in the form of feces, and the remaining enters the kidney by the portal vein and passes out as urine, as shown in Figure 1 [15]. When this bilirubin accumulates in the blood, skin, sclera, and mucous membrane, it turns yellow in color. This yellowness of skin and other parts is generally called jaundice or icterus and is usually seen when the amount of plasma bilirubin is greater than its normal value, i.e., $2 \mathrm{mg} / \mathrm{dL}$ [18].

According to the pathophysiology of jaundice, it is mainly caused due to increased level of bilirubin and its overproduction in the liver, which may occur due to many reasons like acute or minor liver inflammation, obstruction of the bile duct, Gilbert's syndrome, cholestasis, and hemolytic anemia [15]. Jaundice is usually found much more effective and serious in adults rather than in new-born children (neonates), and sometimes it causes even death of the adult individual [19].

Jaundice shows three different stages or types based on its pathophysiology: prehepatic jaundice that is caused due to the hemolysis of red blood cells, also called erythrocytes. Hepatic jaundice occurs due to the abnormal metabolism of the liver or dysfunction of the liver, and post-hepatic jaundice is caused due to less liver functioning or any obstruction in the bile duct, as described in Figure 2.

Jaundice can also be a viral disease, which can spread through contaminated water and food-related items or due to poor sanitization conditions or through several other diseases, such as hepatitis A, hepatitis B, hepatitis C, hepatitis D, liver cancer, and hemolytic 
anemia, etc., which damage liver [14]. It has been estimated that more than two billion people worldwide are infected annually with the hepatitis B virus [20]. The history of jaundice is very long and shown in ancient Ayurveda and the Indian traditional system of medicines [21]. Jaundice is also known as Hariman disease in Rigveda (8000 BC). Herbal treatment is prescribed for jaundice because medicinal plants show a faster rate of reduction in cases when compared with western medicines [22]. This disease shows different kinds of symptoms like weakness, high fever, nausea, loss of appetite, vomiting, and the main symptom shown by this disease is the dark urine color. Sometimes, it also leads to serious conditions like coma, a sudden attack of illness or epileptic fits, psychosis (like having a severe mental disorder), and finally, death of the patient. Precautions or prevention for jaundice generally requires a low-fat diet, high water intake as much body requires, and mainly a healthy diet routine and proper nutrition [15].

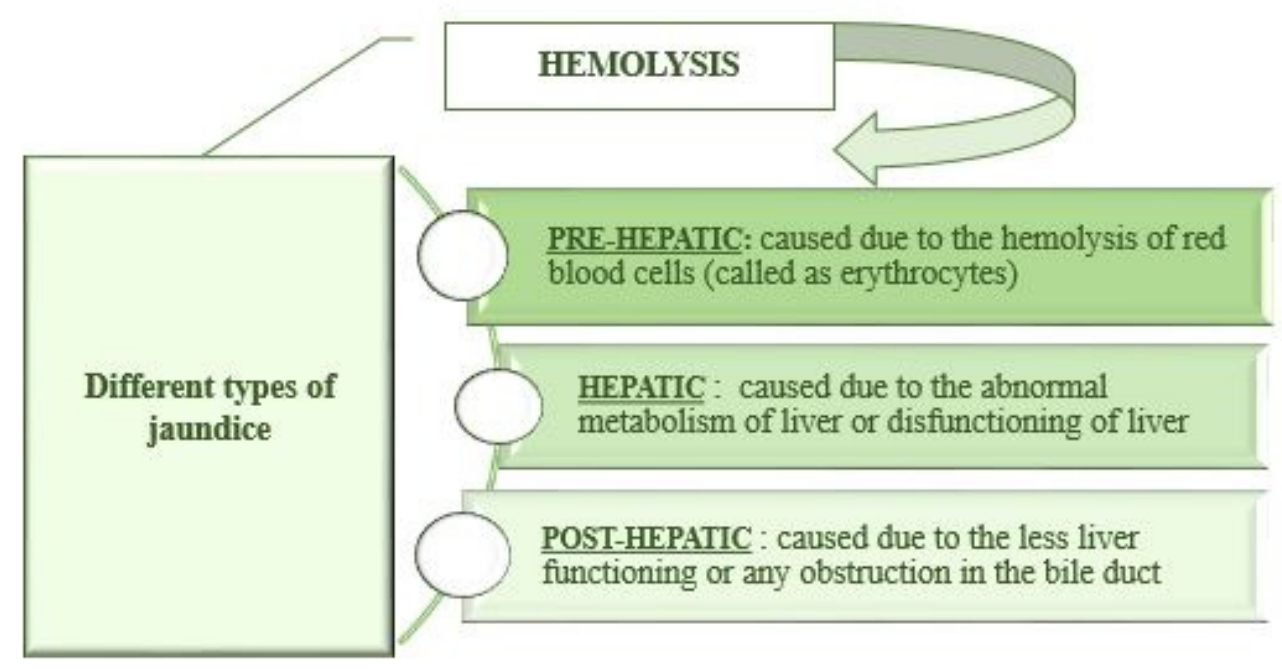

Figure 2. Types of jaundice according to its pathophysiology [15].

Due to cultural or historical reasons and the high cost and side effects of allopathic medicines, traditional and herbal medicines have gained popularity for curing jaundice. So, numerous ethnomedicinal plants have been used by the people of different tribes and communities for treating jaundice based on their indigenous knowledge. Thus, this review is an attempt for the exploration of ethnomedicinal plants used for the treatment of jaundice, which can be cured by locally available plants or with the help of hermits.

\section{Materials and Methods}

All information regarding plants was collected through published data, including the botanical name of plants, family name, part used, and mode of use. The number of articles reviewed were available as published work on online databases (Science Direct, Pubmed, Web of Science, and Google Scholar) and were found using different key phrases (jaundice, ethnomedicinal plants, Himachal Pradesh, traditional uses, western Himalaya, and biological activity). The present study was revised from different scientific articles, including 108 research papers, 30 review papers, and 6 books from 1970 to the 2020 year. Botanical names of different plant species were validated from the online website (www.theplantlist.org).

\subsection{Ethnomedicinal Plants Used in the Treatment of Jaundice in Himachal Pradesh}

It was observed that approximately 87 ethnomedicinal plants are used by the tribal and rural communities of Himachal Pradesh for curing jaundice, and this information is described in Table 1, where plant families are arranged in alphabetical order and include plant's botanical name, common name, family, and region (where these plants were reported). 
Table 1. Ethnomedicinal plants used to cure jaundice by traditional healers in Himachal Pradesh.

\begin{tabular}{|c|c|c|c|c|}
\hline Botanical Name & Local Name & Family & Region & Data Source \\
\hline Justicia adhatoda $\mathrm{L}$. & Basuti, Arusha & Acanthaceae & Kangra, Hamirpur & {$[23,24]$} \\
\hline Adiantum capillus-veneris $\mathrm{L}$. & Dooman tuli & Adiantaceae & Hamirpur & {$[24]$} \\
\hline Pistacia integerrima J. L. Stewart ex Brandis & Kakar Singhi & Anacardiaceae & Hamirpur & [24] \\
\hline Calotropis procera (Aiton) Dryand. & Aak & Apocynaceae & Kangra and Chamba & {$[26]$} \\
\hline Colocasia antiquorum Schott & Ghandiale, Arbi & Araceae & Kangra & {$[23]$} \\
\hline Colocasia esculanata (L.) Schott & Arbi kuchawari & Araceae & Hamirpur & {$[24]$} \\
\hline Hedera helix L. & Kannauri (Bail) & Araliaceae & Shimla & {$[27]$} \\
\hline Crepis flexuosa (Ledeb.) Benth. ex C.B. Clarke & Homa-silli & Asteraceae & Lahul and Spiti & [28] \\
\hline Conyza japonica (Thunb.) Less. ex Less. & Gaadi & Asteraceae & Kullu (Solang Valley) & [29] \\
\hline Picris hieracioides subsp. japonica (Thunb.) Hand-Mazz. & Cherakpa & Asteraceae & Lahul and Spiti & {$[30]$} \\
\hline Scorzonera divaricata Turcz. & Himalayan viper grass & Asteraceae & Lahul and Spiti & {$[31]$} \\
\hline Taraxacum officinale (L.) Weber ex F.H. Wigg. & Dudhli, Dulal & Asteraceae & Kangra, Hamirpur & {$[23,24]$} \\
\hline Youngia tenuifolia (Willd.) Babc. and Stebbins & Seertik & Asteraceae & Lahul and Spiti & [28] \\
\hline Vernonia anthelmintica (L.) Willd. & Kaliziri & Asteraceae & Shimla & [27] \\
\hline Berberis aristata DC. & Kashmal, Chunchari & Berberidaceae & Kangra, Mandi, Shimla, Chamba & {$[23,27,32,33]$} \\
\hline Berberis ceratophylla G. Don & Kashmal & Berberidaceae & Kangra & [34] \\
\hline Berberis chitria Buch. -Ham. ex. Lindl. & Kashmal & Berberidaceae & Shimla & [27] \\
\hline Betula utilis D. Don & Bhojpatra & Betulaceae & Kangra and Chamba & {$[23,32]$} \\
\hline Capsella bursa-pastoris (L.) Medik. & Jangli sarson & Brassicaceae & Kullu (Solang Valley) & [29] \\
\hline Raphanus sativus L. & Muli & Brassicaceae & Kangra, Hamirpur & {$[23,24]$} \\
\hline Oroxylum indicum (L.) Kurz & Tatpalnga & Bignoniaceae & Kangra & {$[23]$} \\
\hline Cassia fistula L. & Kyar, Alsi ki tat & Caesalpinaceae & Kangra & {$[34]$} \\
\hline Tamarindus indica $\mathrm{L}$. & Imli & Caesalpinaceae & Hamirpur & {$[24]$} \\
\hline Capparis spinosa $\mathrm{L}$. & Kabra findus rose & Capparaceae & Lahul and Spiti & {$[31]$} \\
\hline Carica papaya $\mathrm{L}$. & Pump, Papita & Caricaceae & Kangra & {$[23]$} \\
\hline Terminalia bellirica (Gaertn.) Roxb. & Behada & Combretaceae & Solan, Kangra & {$[23,36]$} \\
\hline Terminalia chebula Retz. & Harad & Combretaceae & Kangra, Solan (Kunihar forest divison), and Shimla & {$[23,27,36]$} \\
\hline Cuscuta reflexa Roxb. & Akash bel & Convalvulaceae & Hamirpur, Bilaspur, Solan (Kunihar forest divison) & {$[24,27,37]$} \\
\hline Cucumis sativus L. & Kheera & Cucurbitaceae & Hamirpur & [24] \\
\hline Elaeagnus rhamnoides (L.) A. Nelson & Sea-buck thorn & Elaegnaceae & Lahul and Spiti & [31] \\
\hline Hippophae tibetana Schltdl. & Star bn & Elaegnaceae & Lahul and Spiti & [31] \\
\hline Emblica officinalis Gaertn. & Amla, Amlika & Euphorbiaceae & $\begin{array}{l}\text { Kangra, Shimla, Bilaspur, Chamba, Hamirpur, Sirmour, } \\
\text { Solan, Una }\end{array}$ & {$[23-25,32,37,38]$} \\
\hline Euphorbia hirta L. & Doodhli & Euphorbiaceae & Hamirpur & [24] \\
\hline
\end{tabular}


Table 1. Cont.

\begin{tabular}{|c|c|c|c|c|}
\hline Botanical Name & Local Name & Family & Region & Data Source \\
\hline Euphorbia tirucalli L. & Tohar & Euphorbiaceae & Una, Hamirpur & [39] \\
\hline Mallotus philippinensis Mull.Arg. & Kamla tree, Kumkum & Euphorbiaceae & Kunihar forest division, Solan & [36] \\
\hline Phyllanthus fraternus G.L. Webster & Chota amla, Bhoomi ambla & Euphorbiaceae & Kangra & [23] \\
\hline Ricinus communis $\mathrm{L}$. & Erand & Euphorbiaceae & Kangra & [23] \\
\hline Equisetum arvense $\mathrm{L}$. & Girthan & Equisetaceae & Kangra & [23] \\
\hline Bauhinia variegata L. & Karale, Kachnar & Fabaceae & Kangra & [23] \\
\hline Cajanus cajan (L.) Millsp. & Arhar, Pigeonpea & Fabaceae & Chamba & {$[40]$} \\
\hline Cicer microphyllum Benth. & Chana, Cowpea & Fabaceae & Lahul and Spiti & {$[28]$} \\
\hline Trigonella emodi Benth. & Methi, Fenugreek & Fabaceae & Lahul and Spiti & [31] \\
\hline Flacourtia ramontchi $\mathrm{L}$. & Governor's plum, Bilangra & Flacourtiaceae & $\begin{array}{l}\text { Bilaspur, Chamba, Kangra, Hamirpur, Sirmour } \\
\text { (Nahan), Solan, Una }\end{array}$ & [25] \\
\hline Gentiana kurrroo Royle & Kanauri (Bail) & Gentianaceae & Shimla & [27] \\
\hline Gentiana tubiflora (G. Don) Griseb. & Tikta anupo Mensa & Gentianaceae & Lahul and Spiti & [30] \\
\hline Gentiana leucomelaena Maxim. & Buksuk shipo & Gentianaceae & Lahul and Spiti & {$[30]$} \\
\hline Gentianopsis detonsa (Rottb.) Ma & Chateek & Gentianaceae & Lahul and Spiti & {$[30,31]$} \\
\hline Gentianopsis paludosa (Hook.f.) Ma & Gyatheek & Gentianaceae & Lahul and Spiti & {$[30,31]$} \\
\hline $\begin{array}{l}\text { Gentianella moorcroftiana } \\
\text { (Wall. ex Griseb.) }\end{array}$ & Airy shaw & Gentianaceae & Lahul and Spiti & [31] \\
\hline Aloe vera (L.) Burm.f. & Kware, Ghritkumar, Gavrapatha & Liliaceae & Kangra, Shimla & {$[23,38]$} \\
\hline Asparagus adscendens Roxb. & Sanspan & Liliaceae & Kangra & {$[23]$} \\
\hline Woodfordia fruticosa (L.) Kurz & Dhoaien, Dhai & Lythraceae & Kangra, Hamirpur & {$[23,24]$} \\
\hline Tinospora cordifolia (Willd.) Miers & Giloe, Giloen, Guljae & Menispermaceae & Kangra, Chamba & {$[23,32]$} \\
\hline Morus alba L. & Chitta toot & Moraceae & Hamirpur, Bilaspur & {$[24,37]$} \\
\hline Morus nigra L. & Kala toot & Moraceae & Hamirpur & [24] \\
\hline Leucas cephalotes (Roth) Spreng. & Mal bhedu & Lamiaceae & Kangra & {$[23]$} \\
\hline Boerhavia diffusa L. & Punarnava & Nyctaginaceae & Una and Hamirpur & [39] \\
\hline Argemone mexicana L. & Kantili, Pili Kantili, Bharbhand & Papaveraceae & Kangra, Hamirpur, and Sirmour & {$[23,24,35]$} \\
\hline Sesamum indicum L. & Til & Pedaliaceae & Hamirpur & [24] \\
\hline Polygonum tortuosum D. Don & Agel davaj & Polygonaceae & Lahul and Spiti & [30] \\
\hline Persicaria amplexicaulis (D. Don) Ronse Decr. & Amli/kutrya & Polygonaceae & Chamba and Kangra & [26] \\
\hline Hordeum vulgare L. & Jou, Joui & Poaceae & Hamirpur, Bilaspur & {$[24,37]$} \\
\hline Saccharum officinarum L. & Ganna, Kamandi & Poaceae & Kangra, Bilaspur, and Hamirpur & {$[23,24,37]$} \\
\hline Podophyllum hexandrum Royle & Bankakdi & Podophyllaceae & Manali & [41] \\
\hline Punica granatum $\mathrm{L}$. & Daran & Punicaceae & Hamirpur & {$[24]$} \\
\hline Aquilegia fragrans Benth. & Zadul & Rannunculaceae & Kangra & [34] \\
\hline
\end{tabular}


Table 1. Cont

\begin{tabular}{|c|c|c|c|c|}
\hline Botanical Name & Local Name & Family & Region & Data Source \\
\hline Aconitum rotundifolium Kar. and Kir. & Atish, Patish & Rannunculaceae & Lahul and Spiti & {$[31]$} \\
\hline Thalictrum foliolosum DC. & Pili jari, Chabra & Rannunculaceae & Shimla & [27] \\
\hline Geum elatum Wall. ex G. Don & Gyampar mendok, Turu silva Mensa & Rosaceae & Lahul and Spiti & [30] \\
\hline Rosa webbiana Wall. ex Royle & Seba, Webb's rose & Rosaceae & Lahul and Spiti & [31] \\
\hline Rubia manjith Roxb. ex Fleming & Jamithi, Manjit & Rubiaceae & Manali & {$[42]$} \\
\hline Aegle marmelos (L.) Correa & Bil, Bil patri & Rutaceae & Hamirpur, Bilaspur & {$[24,37]$} \\
\hline Saxifraga flagellaris Willd. & Spider plant & Saxifragaceae & Lahul and Spiti & [28] \\
\hline Capsicum annum L. & Mircha, Pippali & Solanaceae & Kangra & [23] \\
\hline Datura stramonium L. & Dhatura & Solanaceae & Manali & {$[42]$} \\
\hline Solanum nigrum L. & Choote tamatter, Makoi & Solanaceae & Kangra, Hamirpur & {$[23,24]$} \\
\hline Solanum surattense Burm. f. & Kantkari & Solanaceae & Hamirpur & {$[24]$} \\
\hline Centella asiatica (L.) Urb. & Brahmi, Minki & Umblellifereae & Kangra & [23] \\
\hline Urtica dioica $\mathrm{L}$ & Bichu butti & Urticaceae & Manali & {$[42]$} \\
\hline Viola serpens Wall. ex Ging. & Bhanaksha & Violaceae & Hamirpur & [24] \\
\hline
\end{tabular}


The study revealed that these 87 ethnomedicinal plants show variations among them and represent 51 different families of plants used for the treatment of jaundice in Himachal Pradesh. Most of these plant species used for treating jaundice were observed in different areas of Himachal Pradesh, including different districts, such as Kangra, Hamirpur, and Lahul and Spiti, as shown below in Figure 3. Among all these plant species, common medicinal plants belong to six major families, i.e., Asteraceae, Fabaceae, Euphorbiaceae, Gentianaceae, Lamiaceae, and Solanaceae.
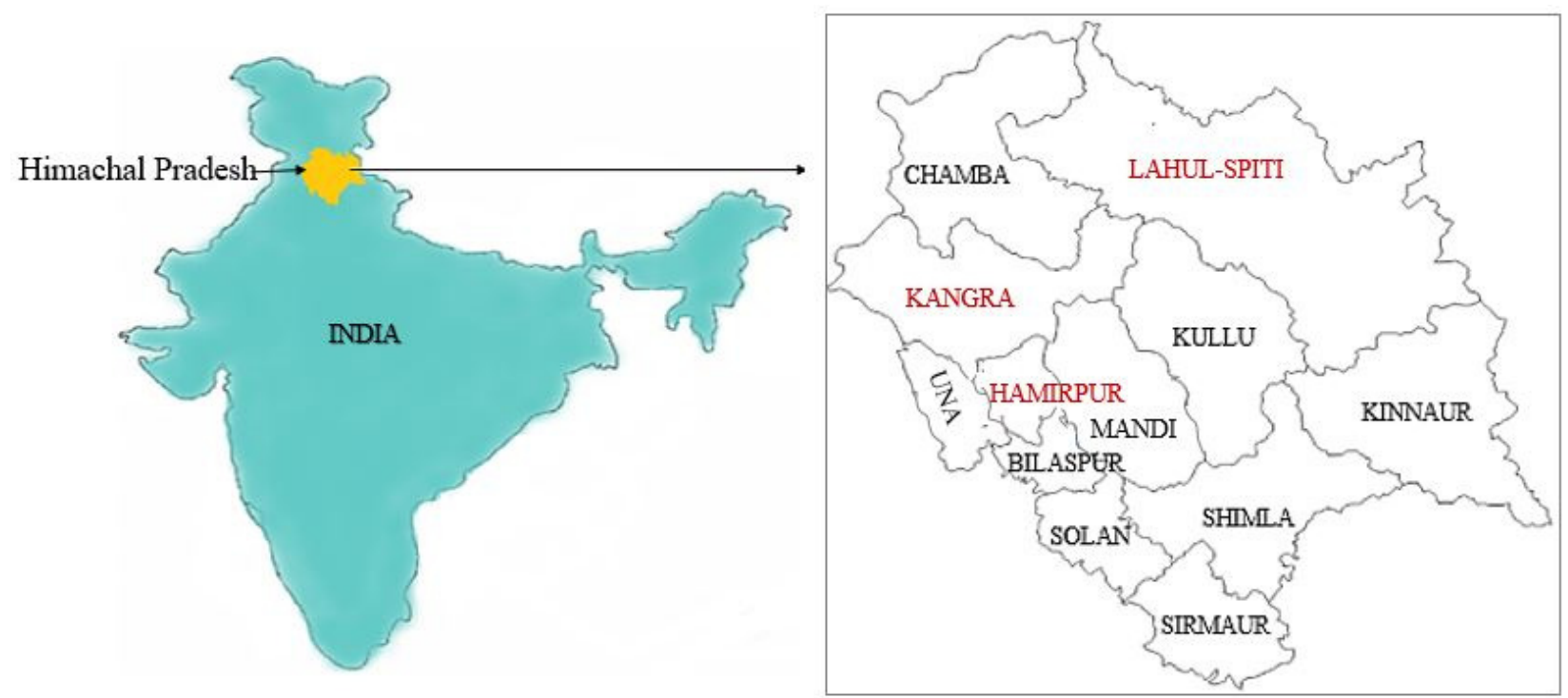

Figure 3. Map of India, showing districts of Himachal Pradesh (district names are added in red font where maximum number of medicinal plants were reported for jaundice treatment).

The plant species most frequently used for the treatment of jaundice include Justicia adhatoda, Emblica officinalis, Ricinus communis, Saccharum officinarum, Terminalia chebula, Berberis aristata, Cuscuta reflexa, and Tinospora cordifolia, and this shows the richness of information regarding medicinal plants used by the people of Himachal Pradesh. Medicinal plants like Aloe vera contains many bioactive compounds, which are responsible for many medicinal properties, such as antibacterial, antioxidants, and immunity-boosting property [18]. Various plant parts have been used for curing jaundice, including stem, leaves, roots, bark, fruits, flowers, seeds, and sometimes even whole plant (described in Table 2). This also strengthens the use of these plants by local people. All ethnomedicinal plants contain some phytochemical constituents, which may be effective in showing an impact on the disease and its cure. The ethnomedicinal significance of plants has been proved by a reassessment of their efficiency potential in different regions. In all the reported plants, there is variation in the usage of plant parts for treating jaundice, which is also shown in Figure 4. This is similar to the work performed in south-western Nigeria, which shows the data analysis of different plant parts used for the treatment of various ailments, including jaundice $[8,43,44]$.

Table 2. Mode of use of ethnomedicinal plants for treating jaundice.

\begin{tabular}{|c|c|c|c|}
\hline Botanical Name & Plant Part Used & Mode of Use & Reference \\
\hline $\begin{array}{l}\text { Aconitum } \\
\text { rotundifolium }\end{array}$ & Whole plant & $\begin{array}{l}\text { Plant juice is taken orally along with an equal volume of } \\
\text { water for five to seven days to cure jaundice. }\end{array}$ & {$[31]$} \\
\hline Adiantum capillus & Leaves & $\begin{array}{l}\text { A decoction of fresh leaves is taken two times for seven } \\
\text { days to cure jaundice. }\end{array}$ & {$[24]$} \\
\hline Aegle marmelos & Leaves and fruit & $\begin{array}{l}\text { A decoction of leaves and unripe fruit is used to } \\
\text { treat jaundice. }\end{array}$ & [24] \\
\hline Ajania tibetica & Leaves and flower & Leaves and flowers are used to cure jaundice. & {$[28]$} \\
\hline
\end{tabular}


Table 2. Cont.

\begin{tabular}{|c|c|c|c|}
\hline Botanical Name & Plant Part Used & Mode of Use & Reference \\
\hline Aloe vera & Fleshy leaves & $\begin{array}{l}\text { The pulp of the leaves is directly consumed by the patient } \\
\text { for two weeks to cure jaundice. }\end{array}$ & [23] \\
\hline Argemone mexicana & Whole plant & Yellow sap of the plant is used to treat jaundice. & [24] \\
\hline Asparagus adscendens & Roots & $\begin{array}{l}\text { A decoction of roots }(10-15 \mathrm{~mL}) \text { is given for eight to ten } \\
\text { days to cure jaundice. }\end{array}$ & [23] \\
\hline Aquilegia fragrans & Seeds & A decoction of seeds is used to treat jaundice. & [34] \\
\hline Bauhinia variegata & Leaves & $\begin{array}{c}\text { Leaves juice is taken for seven days for the } \\
\text { treatment of jaundice. }\end{array}$ & [23] \\
\hline Berberis aristata & New leaves (twigs) and roots & $\begin{array}{l}\text { New leaves are directly consumed, and a decoction of } \\
\text { ground roots (100 mL) is taken to cure jaundice. } \\
\text { Fresh roots are cut into small pieces and further }\end{array}$ & [23] \\
\hline Berberis ceratophylla & Roots & $\begin{array}{l}\text { shade-dried to make pills. These pills are consumed with } \\
\text { "Kujja-Mishri" with water to cure jaundice. }\end{array}$ & [34] \\
\hline Berberis chitria & Roots & A decoction of roots is used to treat jaundice. & [27] \\
\hline Berberis lycium & Roots & A decoction of roots $(80-100 \mathrm{~mL})$ is given to cure jaundice. & [23] \\
\hline Betula utilis & Papery bark & $\begin{array}{l}\text { A decoction of the bark is given to the patient for ten to } \\
\text { twelve days to cure jaundice. }\end{array}$ & [23] \\
\hline Boerhavia diffusa & Whole plant & The whole plant is used to cure jaundice. & [39] \\
\hline Cajanus cajan & Leaves & $\begin{array}{l}\text { Leaf juice or leaf decoction is given with sugar (regularly } \\
\text { in the morning) for about one month to cure jaundice. }\end{array}$ & [40] \\
\hline Calotropis procera & Flowers & $\begin{array}{c}\text { Flowers and betel leaf are taken with honey to } \\
\text { treat jaundice. }\end{array}$ & [26] \\
\hline Capparis spinosa & Shoot & $\begin{array}{l}\text { Stem powder is taken with water at least for } \\
\text { five to six days. }\end{array}$ & [31] \\
\hline Capsella bursa-pastoris & Stem & The stem is used for the treatment of jaundice. & [29] \\
\hline Capsicum annuum & Leaves & $\begin{array}{l}\text { Boiled leaves are used as a vegetable (saag) and given for } \\
\text { two to three days to cure jaundice. }\end{array}$ & [23] \\
\hline Carica papaya & Raw fruit & $\begin{array}{c}\text { Boiled vegetable of raw fruit is given to the patient to } \\
\text { cure jaundice. }\end{array}$ & [23] \\
\hline Carissa opaca & Roots & Roots are used for the treatment of jaundice. & [25] \\
\hline Cassia fistula & Seeds & $\begin{array}{c}\text { A decoction of seeds is consumed empty stomach for a } \\
\text { week, daily in the morning. }\end{array}$ & {$[34]$} \\
\hline Centella asiatica & Whole plant (entire herb) & $\begin{array}{l}\text { The dried herb is crushed with kali mirch, and its paste } \\
(5-10 \mathrm{~g} \text { is taken for seven days to cure jaundice. }\end{array}$ & [23] \\
\hline Cicer microphyllum & Seeds & Seeds are used for the treatment of jaundice. & [28] \\
\hline Colocacia antiquorum & Corm & $\begin{array}{l}\text { Corm (cooked or pealed) is kept in open places overnight. } \\
\text { In the morning, chopped pieces are given with honey to } \\
\text { the patient for five days. }\end{array}$ & [23] \\
\hline Colocacia esculenta & Bulb & $\begin{array}{c}\text { The dried bulb in the powder form is used for the } \\
\text { treatment of jaundice. }\end{array}$ & [24] \\
\hline Conyza japonica & Leaves & Leaf paste is used to cure jaundice. & [29] \\
\hline Cucumis sativus & Fruit & $\begin{array}{l}\text { Fresh fruit is cut into small pieces and taken thrice a day } \\
\text { for three weeks to cure jaundice. }\end{array}$ & [24] \\
\hline Cuscuta reflexa & Whole plant & A decoction of the whole plant is used to treat jaundice. & [24] \\
\hline Crepis flexuosa & Whole plant & $\begin{array}{l}\text { Whole plant juice is mixed with water in equal proportion } \\
\text { and taken once a day to cure jaundice. }\end{array}$ & {$[31]$} \\
\hline Datura stramonium & Leaves and fruit & Fruits and leaves are used to cure jaundice. & [42] \\
\hline Emblica officinalis & Roots & $\begin{array}{c}\text { A decoction of roots is recommended for two weeks to } \\
\text { cure jaundice. }\end{array}$ & [24] \\
\hline Elaeagnus rhamnoides & Fruit & Fruit juice is used to cure jaundice. & [31] \\
\hline Euphorbia hirta & Stem and leaves & Stem and leaf extract is used to cure jaundice. & [24] \\
\hline Euphorbia tirucalli & Leaves & $\begin{array}{l}\text { A decoction of leaves is used for the treatment of jaundice. } \\
\text { Young branches are dipped in the water overnight, and }\end{array}$ & [39] \\
\hline Equisetum arvense & Young branch & $\begin{array}{l}\text { juice is (mix a small quantity of Kujja-Mishri and two and } \\
\text { a half kali mirch seeds) taken daily empty stomach at least } \\
\text { for seven days to cure jaundice. }\end{array}$ & [23] \\
\hline Flacourtia ramontchi & Bark, fruits, and roots & Bark, fruits, and roots are used to treat jaundice. & [25] \\
\hline Gentiana kurrroo & Roots & The root powder is used for treating jaundice. & [27] \\
\hline
\end{tabular}


Table 2. Cont.

\begin{tabular}{|c|c|c|c|}
\hline Botanical Name & Plant Part Used & Mode of Use & Reference \\
\hline Gentiana tubiflora & Whole plant & $\begin{array}{c}\text { The whole plant is ground with lazi (salted curd) to form } \\
\text { a paste and given for forty to forty-five days } \\
\text { to cure jaundice. }\end{array}$ & {$[30]$} \\
\hline $\begin{array}{l}\text { Gentiana leucomelaena } \\
\text { Gentianopsis detonsa } \\
\text { Gentianopsis paludosa }\end{array}$ & Whole plant & $\begin{array}{l}\text { Plants are crushed with a small proportion of petals of } \\
\text { Polemonium caerulem, and this mixture is given with curd } \\
\text { or cow milk empty stomach for fifteen to twenty-two days } \\
\text { to cure jaundice. }\end{array}$ & {$[30]$} \\
\hline Gentianella moorcroftiana & Aerial plant part & $\begin{array}{l}\text { Juice of fresh extracted aerial plant part is taken empty } \\
\text { stomach to cure jaundice. }\end{array}$ & [31] \\
\hline Gernaium nepalenses & Roots & $\begin{array}{c}\text { Root powder }(2 \mathrm{~g}) \text { is administered thrice a day } \\
\text { to cure jaundice. }\end{array}$ & [42] \\
\hline Geum elatum Wallich & Leaves & $\begin{array}{l}\text { Leaves extract, mixed with cow milk or curd, is given for } \\
\text { fifteen to twenty-two days to cure jaundice. }\end{array}$ & [30] \\
\hline Hedera helix & Leaves & Crushed leaves' juice is used to cure jaundice. & [27] \\
\hline Hippophae tibetana & Fruit & A decoction of the fruit is taken to cure jaundice. & [31] \\
\hline Hordeum vulgare & Seeds & $\begin{array}{c}\text { Dried seed powder is mixed with a sugar solution } \\
\text { to cure jaundice. }\end{array}$ & [37] \\
\hline Justicia adhatoda & Roots & $\begin{array}{c}\text { A decoction of its roots is given to the patient for one } \\
\text { month to cure jaundice. }\end{array}$ & {$[24]$} \\
\hline Leucas cephalotes & Entire herb & $\begin{array}{l}\text { Juice of the entire herb }(10-15 \mathrm{~mL}) \text { is given to the patient } \\
\text { for eight to ten days. }\end{array}$ & {$[23,36]$} \\
\hline Mallotus philippinensis & Seeds & Seed powder is given for the treatment of jaundice. & \\
\hline Mentha spicata & Leaves & $\begin{array}{l}\text { Fresh leaf juice is taken with Kujja-Mishri and given twice } \\
\text { a day for two or more weeks. }\end{array}$ & [23] \\
\hline Morus alba & Fruit & Fruit juice is used for treating jaundice. & {$[24]$} \\
\hline Morus nigra & Fruit & $\begin{array}{l}\text { Fresh fruit juice is given to the patients twice a day for } \\
\text { two weeks. }\end{array}$ & {$[24]$} \\
\hline Oroxylum indicum & Bark of the stem & $\begin{array}{l}\text { Crushed bark is soaked in water overnight and given with } \\
\text { a small amount of kapoor to cure jaundice. A decoction of } \\
\text { the bark is also used for treating jaundice. }\end{array}$ & [23] \\
\hline Persicaria amplexicaulis & Whole plant & $\begin{array}{c}\text { A decoction of the whole plant is given orally } \\
\text { to treat jaundice. }\end{array}$ & [26] \\
\hline Picris hieracioides & Whole plant & $\begin{array}{l}\text { Plant extract with salted curd is given to the patient for } \\
\text { twenty to thirty days. }\end{array}$ & [30] \\
\hline Pistacia integerrima & Fruit & $\begin{array}{c}\text { Fresh fruit juice is given daily for seven days } \\
\text { to curing jaundice. }\end{array}$ & [24] \\
\hline Phyllanthus fraternus & Whole plant, roots & $\begin{array}{l}\text { A decoction of the entire herb and juice of fresh roots is } \\
\text { given for seven days to cure jaundice. }\end{array}$ & [23] \\
\hline Picrorhiza kurroa & Rhizome & Rhizome powder is used to cure jaundice. & {$[24]$} \\
\hline Polygonum tortuosum & Whole plant & $\begin{array}{l}\text { A paste of the whole plant is mixed with curd (prepared } \\
\text { from goat's milk) and given an empty stomach for fifteen } \\
\text { to twenty-two days. }\end{array}$ & [30] \\
\hline Podophyllum hexandrum & Flower and leaves & $\begin{array}{c}\text { The juice of flowers and leaves is mixed with butter and } \\
\text { taken orally to cure jaundice. }\end{array}$ & [41] \\
\hline Prunus domestica & Fruit & The fruit extract is used for the treatment of jaundice. & [24] \\
\hline Punica granatum & Fruit and seeds & $\begin{array}{l}\text { Seeds and fruit powder is taken with water and sugar } \\
\text { solution to cure jaundice. }\end{array}$ & [24] \\
\hline Raphanus sativus & Root and fleshy part & $\begin{array}{c}\text { A decoction of roots and juice of fleshy part is given to } \\
\text { cure jaundice. }\end{array}$ & [24] \\
\hline Ricinus communis & Leaves & $\begin{array}{l}\text { Leaf juice is given with cow's milk early in the morning } \\
\text { for seven days to treat jaundice. }\end{array}$ & [23] \\
\hline Rosa webbiana & Fruit & $\begin{array}{l}\text { Fruit powder is mixed with little quantity of water and } \\
\text { taken daily to cure jaundice. }\end{array}$ & [31] \\
\hline Rubia manjith & Roots and stem & Roots and stem paste is given to cure jaundice. & [42] \\
\hline Saccharum officinarum & Stem & Stem juice is used to cure jaundice. & {$[24]$} \\
\hline Saxifraga flagellaris & Leaves and stem & Leaves and stems are used to cure jaundice. & [28] \\
\hline Scorzonera divaricata & Leaves and shoot & $\begin{array}{c}\text { A decoction of leaves and shoots is taken orally } \\
\text { to cure jaundice. }\end{array}$ & [31] \\
\hline
\end{tabular}


Table 2. Cont.

\begin{tabular}{|c|c|c|c|}
\hline Botanical Name & Plant Part Used & Mode of Use & Reference \\
\hline Sesamum indicum & Leaves & Powder made from fresh leaves is used to cure jaundice. & [24] \\
\hline Solanum nigrum & Leaves & $\begin{array}{l}\text { Tablets are made from crushed leaves and taken with imli } \\
\text { (tamarind) or curd for treating jaundice. }\end{array}$ & [23] \\
\hline Solanum surattense & Fruit & $\begin{array}{c}\text { The fruit is directly consumed for the } \\
\text { treatment of jaundice. }\end{array}$ & [24] \\
\hline Tamarindus indica & Fruit and root & $\begin{array}{l}\text { A decoction of its roots is used to treat jaundice. The fruit } \\
\text { is also used to cure jaundice. }\end{array}$ & [24] \\
\hline Taraxacum officinale & $\begin{array}{l}\text { Root and leaves and } \\
\text { whole herb }\end{array}$ & $\begin{array}{l}\text { The entire herb in the crushed form }(10 \mathrm{gm}) \text { is given to the } \\
\text { patient for ten days to curing jaundice. }\end{array}$ & [23] \\
\hline Terminalia bellirica & Leaves & A decoction of leaf powder is taken to cure jaundice. & [36] \\
\hline Terminalia chebula & $\begin{array}{l}\text { Fruit } \\
\text { rind }\end{array}$ & $\begin{array}{l}\text { Fruit powder is mixed with rock salt and taken with } \\
\text { warm water for eight to ten days to cure jaundice. }\end{array}$ & [23] \\
\hline Thalictrum foliolosum & Roots & A decoction of roots is used to treat jaundice. & [27] \\
\hline Tinospora cordifolia & Fresh stem & $\begin{array}{l}\text { The dried stem of the giloe is crushed with punarnava } \\
\text { mool, and its juice is taken for seven to ten days. }\end{array}$ & [23] \\
\hline Trigonella emodi & Leaves and flower & $\begin{array}{l}\text { Leaves and flower powder is taken with water twice a day } \\
\text { for seven to ten days. }\end{array}$ & [31] \\
\hline Urtica dioica & Whole plant & The whole plant is used to treat jaundice. & [42] \\
\hline Vernonia anthelmintica & Seeds and leaves & A decoction of seeds and leaves is given to cure jaundice. & [27] \\
\hline Viola serpens & Whole plant & $\begin{array}{l}\text { A decoction of dried plant is taken with sugar for more } \\
\text { than fifteen days. }\end{array}$ & [24] \\
\hline Woodfordia fruticosa & Flowers & Flower extract is used to cure jaundice. & [24] \\
\hline Youngia tenuifolia & Leaves & Leaves are used to treat jaundice. & [28] \\
\hline
\end{tabular}

\section{PERCENTAGE OF PLANT PART USED}

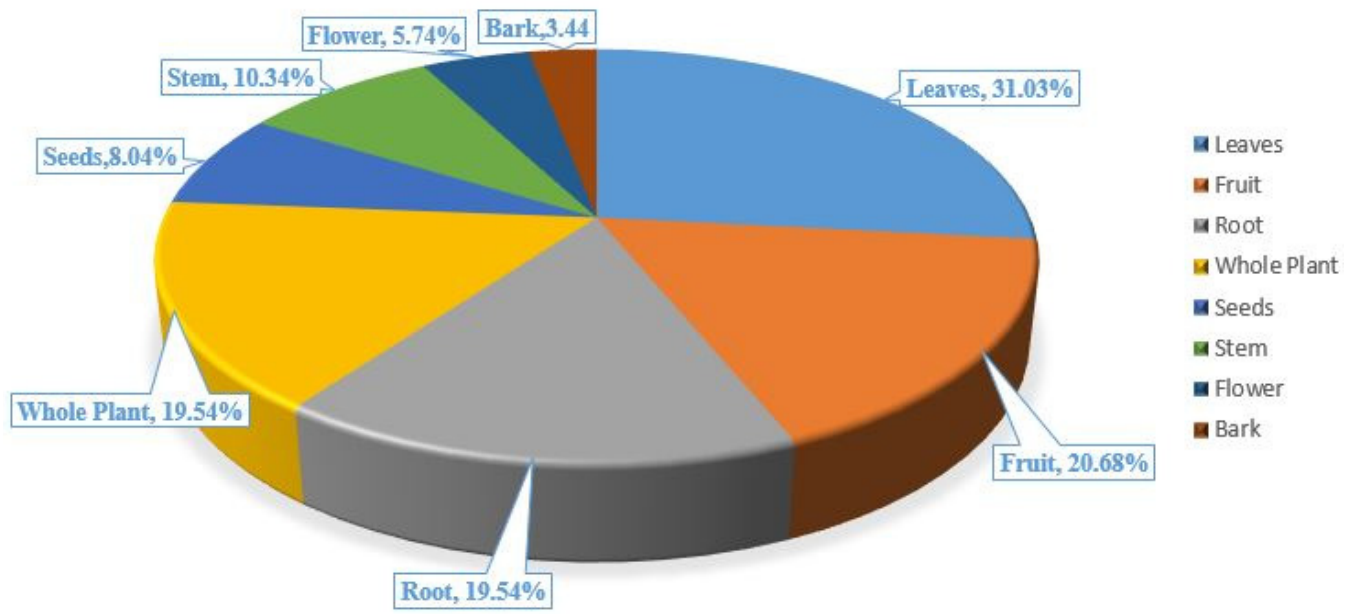

Figure 4. Analysis of the data showing a total estimation of plant parts used for the treatment of jaundice $[8,44]$.

\subsection{Mode of Plant Used for the Treatment of Jaundice in Himachal Pradesh}

Traditionally, people of Himachal Pradesh use these plant species in appropriate dosages or amounts for curing jaundice. There are different methods of usage of these medicinal plants, like in district Hamirpur, bulb of Colocasia esculenta is cooked as a vegetable, the dried bulb is cut into pieces and then crushed to make powder and given orally to treat jaundice, and juice of fresh Pistacia integerrima is given daily to cure jaundice [24]. Uses of other ethnomedicinal plants are described in Table 2, which includes the plant's botanical name, plant part used, and mode of use (route of administration) of these plants for treating jaundice. In most cases, these plants are taken alone as a decoction or with a combination of the talmishri or kali mirch. On the other hand, some plants are also taken in combination with other plants, e.g., Emblica officinalis fruit is taken along with 
the Terminalia chebula and Terminalia bellirica fruits, grounded into powder form, and taken orally to cure jaundice [25].

The above pie-chart highlights the different plant parts commonly used for the treatment of jaundice, as analyzed from data in Table 2. It was observed that for jaundice treatment, leaves are highly utilized $(31.03 \%)$, followed by fruits $(20.68 \%)$, roots $(19.54 \%)$, whole plant $(19.54 \%)$, seeds $(8.04 \%)$, stem $(10.34 \%)$, flowers $(5.74 \%)$, and bark $(3.44 \%)$; the same pattern is also shown in Figure 3. This indicates that in most cases, the leaves of medicinal plants have more significance than any other plant part. Hence, it can be concluded that leaves are highly effective for curing jaundice, which may be due to more phytochemical accumulation in the plant leaves. However, fruits are the second most used to treat jaundice, root belongs to the third position for treating jaundice, and bark is utilized in the least cases.

Intake of these ethnomedicinal plant parts is suggested to be continued for a definite period or until full recovery. Thus, plants are suggested to be taken in the form of paste, decoction, extract, and dried powder form. Different plant parts contain various organic compounds within them, called secondary metabolites, which may be the reason behind the effectiveness of plant-based treatments and show various chemical and physiological actions against jaundice. These phytoconstituents include proteins, carbohydrates, steroids, terpenoids, alkaloids, saponins, phenols, flavonoids, vitamins, tannins, and essential oils, which show an inhibitory effect against hepatoprotective diseases, mainly against jaundice $[45,46]$. T. chebula contains a significant amount of phenolic and flavonoid compounds. The main constituents of the plant include 2,4-chebulyl- $\beta$-D-glucopyranose, ellagic acid, gallic acid, and chebulic ellagitannins. T. chebula is one of the main components of the important Ayurvedic formulation "Triphala" (infusion of three fruits, i.e., T. chebula, T. bellirica, and Emblica officinalis). Ayurveda prescribes this formulation to cure kidney and liver dysfunctions. T. chebula extract ensures hepatoprotection against liver diseases, such as jaundice, due to its antioxidant activity and bilirubin level lowering effect. The reduction in serum bilirubin level is the most important evidence, which supports the traditional use of the plant against jaundice [47].

\subsection{Phytochemical Constituents Present in the Ethnomedicinal Plants}

The medicinal property of plants is mainly because of the formation or stimulation of various chemical compounds that occur naturally in the plants and hence used to cure jaundice and various other diseases. So, this review describes various phytochemical constituents present in the ethnomedicinal plants used by people of Himachal Pradesh for curing jaundice, and the data is taken from different sources. The plants are further used for the development of antimicrobial and antioxidant drugs [48], thus proving their medicinal worth. Plant like Justicia adhatoda consists of various organic [49] and bioactive compounds [50], which possess numerous biological activities, such as antitussive, abortifacient, cardiovascular protection, anti-inflammatory, and antimicrobial. Berberis lycium plant shows the presence of tannins, terpenoids, fats, resins, and many active alkaloids. The roots are the foremost important part of the Berberis species as they contain a variety of alkaloids, and the most prominent one is berberine. It has been found that the inhibitory activity of Berberis lycium is shown by the components present in its root extract [51]. Like this, many other plants are used in the treatment of jaundice, possessing various phytochemical constituents, out of which some predominant phytochemicals are described in Table 3.

Table 3. Major phytochemicals present in ethnomedicinal plants used for curing jaundice in Himachal Pradesh.

\begin{tabular}{cccc}
\hline Plant Name & Phytochemical Constituent & Data Source \\
\hline Aconitum rotundifolium & Diterpenoid alkaloids (isoatisine, atisine chloride) & [52] \\
Adiantum capillus-veneris & Flavonoids, phenolic acids (sulfate esters of hydroxycinnamic acid), alkaloids, & terpenoids (triterpenes), steroids, tannins, saponins \\
Aegle marmelos & $\begin{array}{l}\text { Phenolic compounds (coumarins, such as marmelosin, marmesin, imperatorin, } \\
\text { scopoletin, and esculetin), alkaloids (aeglin, aegelenine, skimmianine), tannins }\end{array}$ & [54] \\
\hline
\end{tabular}


Table 3. Cont.

\begin{tabular}{|c|c|c|}
\hline Plant Name & Phytochemical Constituent & Data Source \\
\hline Ajania tibetica & $\begin{array}{c}\text { Terpenoids (bornyl acetate } 60.7 \%, \beta \text {-caryophyllene } 9.1 \% \text {, } \beta \text {-eudesmol } 5.3 \% \text {, methyl } \\
\text { thymol } 4.3 \% \text { and borneol } 2.2 \% \text { ) }\end{array}$ & [55] \\
\hline Aloe vera & $\begin{array}{c}\text { Fatty acids (such as n-hexadecanoic acid } 20.47 \% \text {, oleic acid } 14.53 \% \text {, tetradecanoic } \\
\text { acid } 1.04 \% \text {, 1,2-benzenedicarboxylic acid, diisooctyl ester } 13.60 \% \text {, squalene } 6.60 \% \text {, } \\
\text { butyl octyl ester } 2.30 \% \text { ) }\end{array}$ & [56] \\
\hline Argemone mexicana & $\begin{array}{l}\text { Alkaloids (argemexicaine A, argemexicaine B, protopine, columbamin, muramine, } \\
\text { cryptopine, isocorydine), carbohydrates (arabinose, lactose), steroids ( } \beta \text {-sitosterol, } \\
\text { stigma-4-en-3,6-dione), terpenoids ( } \beta \text {-amyrin, trans-phytol), flavonoids (eriodictyol, } \\
\text { luteolin, quercetin, rutin), tannins, phenolic acids (vanillic acid) }\end{array}$ & [57] \\
\hline Asparagus adscendens & Saponins and steroids (stigmasterol glycosides) & [26] \\
\hline Aquilegia fragrans & $\begin{array}{l}\text { Steroids ( } \beta \text {-sitosterol), 2,4-dihydroxyphenylacetic acid methyl ester, aquilegiolide, } \\
\text { glochidiono lactone- } \mathrm{A} \text {, and alkaloids (magnoflorine) }\end{array}$ & [58] \\
\hline Bauhinia variegata & Terpenoids, flavonoids, tannins, saponins, steroids, and cardiac glycosides & [26] \\
\hline Berberis aristata & $\begin{array}{c}\text { Phenolic acids (e-caffeic acid, chlorogenic acid), flavonoids (quercetin, rutin), and } \\
\text { alkaloids (berberine, berbamine, palmatine, columbamine, } \\
\text { jatrorrhizine, oxyacanthine) }\end{array}$ & [59] \\
\hline Berberis lycium & $\begin{array}{c}\text { Alkaloids (berberine, berbamine, chenabine, karakoramine, palmatine, } \\
\text { baluchistanamine, gilgitine, jhelumine, punjabine, sindamine) }\end{array}$ & [26] \\
\hline Betula utilis & $\begin{array}{l}\text { Terpenoids (betulin, betulinic acid, oleanolic acid, acetyl-oleanolic acid, lupeol, } \\
\text { lupenone, methyl betulonate, methyl betulate, karachic acid), steroids (sitosterol), } \\
\text { flavonoids (leucocyanidin, polymeric leucoanthocyanidins) }\end{array}$ & {$[60]$} \\
\hline Boerhavia diffusa & $\begin{array}{c}\text { Flavonoids (rotenoids, quercetin, kaempferol, borhaavone), lignans, steroids, } \\
\text { phenolic glycosides, phenolic compounds (trans-caftaric acid, xanthones), fatty } \\
\text { acids, and hydrocarbons }\end{array}$ & [61] \\
\hline Cajanus cajan & Carbohydrates $26.425 \pm 0.32$, proteins $12.83 \pm 0.285$, lipids and phenols & [62] \\
\hline Calotropis procera & $\begin{array}{l}\text { Alkaloids (calotropin, calotoxin, uskerin), flavonoids, tannins, saponins, cardiac } \\
\text { glycosides, volatile oil, and steroids }\end{array}$ & [26] \\
\hline Capparis spinosa & $\begin{array}{l}\text { Flavonoids (flavonol, quercetin-7-O- } \beta \text {-d-glucopyranoside- } \beta \text {-l-rhamnopyranoside, } \\
\text { quercetin-3-rutinoside, rutin), fatty oil, carbohydrates (pentosans), and saponin }\end{array}$ & [31] \\
\hline Capsella bursa-pastoris & $\begin{array}{l}\text { Fatty acids (dodecanoic acid } 5.66 \pm 1.17 \text {, tetradecanoic acid } 29.63 \pm 5.79, \\
\text { pentadecanoic acid } 18.05 \pm 3.06, \text { hexadecanoic acid } 284.48 \pm 41.06, \text { heptadecanoic } \\
\text { acid } 7.11 \pm 1.60, \text { octadecanoic acid } 53.20 \pm 0.68 \text {, eicosanoic acid } 2.52 \pm 0.33 \text { ), } \\
\text { steroids (phytosterol, cholesterol, campesterol, stigmasterol, } \beta \text {-sitosterol), amino } \\
\text { acids (glycine, histidine), and flavonoids (tricin, kaempferol, quercetin) }\end{array}$ & [63] \\
\hline Capsicum annum & $\begin{array}{l}\text { Alkaloids (capsaicin } 0.5 \%-0.9 \% \text { ), glycosides, carbohydrates, steroids, terpenoids } \\
\text { (triterpenes), and carotenoids (capsanthin, capsorubin } 4-16 \% \text { ) }\end{array}$ & [64] \\
\hline Carica papaya & Flavonoids, saponins, tannins, glycosides, and steroids & [65] \\
\hline Carissa opaca & $\begin{array}{c}\text { Cardiac glycosides (digitoxigenin-3-O- } \beta \text {-d-digitalopyranoside), phenolic } \\
\text { compounds, lignans, terpenoids (17-hydroxy-11-oxo-nor- } \beta \text {-amyrone, urs- } 12 \text {-ene- } 3 \beta \text {, } \\
22 \beta \text {-diol-17-carboxylic acid), steroids (stigmasterol, campesterol, } \beta \text {-sitosterol), } \\
\text { flavonoids (rutin, quercetin), essential oils (hydroxyacetophenone } 89.5 \% \text {, benzyl } \\
\text { salicylate } 6.0 \% \text {, benzyl benzoate } 4.6 \% \text {, }(\mathrm{E}, \mathrm{E})-\alpha \text {-farnesene } 3.5 \%), \text { protein }(1.3 \%), \\
\text { and carbohydrates }(17.39 \%)\end{array}$ & [66] \\
\hline Cassia fistula & $\begin{array}{l}\text { Terpenoids (lupeol), steroids ( } \beta \text {-sitosterol), fatty acid alcohols (hexacosanol), } \\
\text { flavonoids (kaempferol, leucopelargonidin, rhamnetin-3-O-gentiobioside), phenolic } \\
\text { acids (rhein, 3-formyl-1-hydroxy-8- methoxy anthaquinone), and alkaloids }\end{array}$ & [26] \\
\hline Centella asiatica & Alkaloids, glycosides, terpenoids, steroids, flavonoids, tannins, and reducing sugars & [67] \\
\hline Cicer microphyllum & $\begin{array}{c}\text { Steroids (phytosterols), flavonoids, phenolic compounds, tannins, carbohydrates, } \\
\text { proteins, and amino acids }\end{array}$ & [68] \\
\hline Colocasia esculenta & $\begin{array}{l}\text { Flavonoids (flavones, apigenin, luteolin, anthocyanins), carbohydrate (starch } \\
0.23-0.52 \% \text { ), and lipids } 0.017-0.025 \%\end{array}$ & [69] \\
\hline Conyza japonica & $\begin{array}{c}\text { Terpenoids (sesquiterpenoids, conyterpenols A-D, strictic acids), flavonoids, } \\
\text { and their glycosides }\end{array}$ & [70] \\
\hline Crepis flexuosa & $\begin{array}{l}\text { Phenolic acids (p-hydroxybenzoic acid, ethyl p-hydroxybenzoate, esculetin) } \\
\text { terpenoids (taraxast-20(30)-ene-3 } \beta, 21 \alpha \text {-diol, ursolic acid, oleanolic acid), flavonoids } \\
\text { (apigenin, luteolin, luteolin-7-O- } \beta \text {-D-glucoside), fatty acids (octacosanoic acid, } \\
2^{\prime}, 3^{\prime} \text {-dihydroxypropyl pentacosanoate), and steroids (daucosterol) }\end{array}$ & [71] \\
\hline
\end{tabular}


Table 3. Cont.

\begin{tabular}{|c|c|c|}
\hline Plant Name & Phytochemical Constituent & Data Source \\
\hline Cuscuta reflexa & $\begin{array}{c}\text { Flavonoids (aromandendrin), glycosides, carotenoids (lutein- 10-22\%, lycopene), } \\
\text { alkaloids, steroids (campesterol, stigmasterol, } \\
\text { stigmast-5-en-3-O- } \beta \text {-D-glucopyranoside), lignin (sesamin), and terpenoids } \\
\text { (lupeol, maragenin) }\end{array}$ & [72] \\
\hline Cucumis sativus & $\begin{array}{l}\text { Steroids, glycosides, flavonoids, alkaloids, saponins, and tannins } \\
\text { (except gums and reducing sugars) }\end{array}$ & [73] \\
\hline Datura stramonium & Alkaloids (atropine, hyoscyamine, scopolamine), glycosides, saponins, and tannins & [74] \\
\hline Elaeagnus rhamnoides & $\begin{array}{l}\text { Alkaloids (carboline), terpenoids (ursolic acid, uvaol, amyrin), flavonoids (quercetin, } \\
\text { myricetin, isorhamnetin, glucosides, rutin), carotenoids, fatty oil, and steroids } \\
\text { (sitosterol, citrostandienol) }\end{array}$ & [31] \\
\hline Emblica officinalis & $\begin{array}{c}\text { Phenolic acids (propnyl 3,4,5-trihydroxybezonate, 2,3,7,8-tetrahydroxy chromeno } \\
\text { [5,4,3-cde]chromene-5,10-dione, chlorogenic acid, ellagic acid), flavonoids (rutin, } \\
\text { quercetin), tannins, amino acids, fixed oils }\end{array}$ & [75] \\
\hline Euphorbia hirta & Terpenoids (diterpenes, triterpenes), phenolic acids (coumarins), and lignans & [76] \\
\hline Euphorbia tirucalli & $\begin{array}{l}\text { Fatty acids (palmitic acid, linoleic acid), steroids (sitosterol, stigmasterol, } \\
\text { campesterol), flavonoids (anthocyanin, cyanidin glycoside) }\end{array}$ & {$[77]$} \\
\hline Equisetum arvense & $\begin{array}{c}\text { Flavonoids } 0.6-0.9 \% \text { (such as apigenin-5-O-glucoside, genkwanin-5-O-glucoside, } \\
\text { kaempferol-3,7-di-O-glucoside, } \\
\text { kaempferol-3-O-(6'-O-malonylglucoside)-7-O-glucoside, } \\
\text { kaempferol-3-O-sophoroside, luteolin-5-O-glucoside, quercetin-3-O-glucoside), } \\
\text { terpenoids (cis-geranyl acetone } 13.74 \% \text {, thymol } 12.09 \% \text {, trans-phytol } 10.06 \% \text {, } \\
\text { triterpenes), alkaloids, carbohydrates, proteins, amino acids, steroids (phytosterols), } \\
\text { saponins, and tannins }\end{array}$ & [78] \\
\hline Flacourtia ramontchi & Saponins, steroids, sugar, lignans, and terpenoids (triterpenes) & [79] \\
\hline Geranium nepalenses & $\begin{array}{c}\text { Steroids ( } \beta \text {-sitosterol, } \beta \text {-sitosterol-glactoside, stigmasterol) and } \\
\text { terpenoids (ursolic acid) }\end{array}$ & [80] \\
\hline Gentiana kurroo & Terpenoids (iridoids, triterpenoids), flavonoids, alkaloids & [81] \\
\hline Gentianopsis paludosa & $\begin{array}{l}\text { Flavonoids (luteolin), xanthones (gentiacaulein, } \\
\text { phenolics-1-hydroxy-3,7,8-trimethoxyxanthone), terpenoids (ursolic acid), } \\
\text { dicarboxylic acid-succinic acid }\end{array}$ & [31] \\
\hline Gentianopsis detonsa & $\begin{array}{l}\text { Flavonoids (luteolin), dicarboxylic acid-succinic acid, xanthones (gentiacaulein, } \\
\text { 1-hydroxy-3,7,8-trimethoxyxanthone), terpenoids (ursolic acid) }\end{array}$ & [31] \\
\hline Geum elatum & $\begin{array}{c}\text { Fatty acid alcohols (hentriacontanol, hentriacontanone), sterols ( } \beta \text {-sitosterol), } \\
\text { phenolic acids (tetra-O-methyl ellagic acid, ellagic acid), and flavonoids } \\
\text { (isoquercetrin) }\end{array}$ & [82] \\
\hline Hedera helix & $\begin{array}{c}\text { Phenolic acids (gallic acid } 131.25 \pm 1.54 \text { ), flavonoids (quercetin } 18.61 \pm 0.37 \text { ), } \\
\text { alkaloids (emetine), amino acids, and saponins } \\
\text { (hederacoside C, } \alpha \text {-hederin, hederagenin) }\end{array}$ & [83] \\
\hline Hippophae tibetana & $\begin{array}{l}\text { Flavonoids (isorhamnetin, quercetin, kaempferol, rhamnetin, quercetin -3-O- } \\
\text { rutinoside, quercetin-3-O-galactoside), fatty acids (2-hydroxydecanoic acid, } \\
\text { nona-7-enoic acid, undec-9-en-7-ynoic acid, 13-phenyl tridecanoic acid, } \\
\text { 5,9,21-nonacosatrienoic acid, 1,3-dicapryloyl-2- linoleoylglycerol, oleic, linoleic, } \\
\text { linolenic acids and fats 3.5-4.8\%) }\end{array}$ & [84] \\
\hline Hordeum vulgare & Flavonoids, phenolic acids, terpenoids, glycosides, and saponins & [85] \\
\hline Justicia adhatoda & $\begin{array}{l}\text { Alkaloids (vasicine, vasicol, vasicinone, peganine, adhatonine, vasicinol, } \\
\text { vasicinolone), flavonoids (kaempferol, quercetin), and steroids ( } \beta \text {-sitosterol) }\end{array}$ & {$[26,86]$} \\
\hline Leucas cephalotes & $\begin{array}{c}\text { Phenolic acids (gallic acid, protocatechuic acid, chlorogenic acid, caffeic acid, } \\
\text { and ferulic acid) }\end{array}$ & [26] \\
\hline Mentha spicata & $\begin{array}{l}\text { Fatty acids (methyl esters, methyl acetate } 2-11 \% \text { ), terpenoids (menthol } 33-60 \% \text {, } \\
\text { menthone } 15-32 \% \text {, isomenthone } 2-8 \%, 1,8 \text { cineole eucalyptol } 5-13 \% \text {, menthofuaran } \\
1-10 \% \text {, limonene } 1-7 \% \text { ), flavonoids, alkaloids, and sugars }\end{array}$ & [87] \\
\hline Morus alba & $\begin{array}{l}\text { Phenolic acids (coumarins, benzofurans), flavonoids (chalcones, flavones, flavane } \\
\text { derivative, }(2 S)-4^{\prime} \text {-hydroxy-7-methoxy-8-prenylflavan) }\end{array}$ & [88] \\
\hline Morus nigra & $\begin{array}{c}\text { Phenolic acids, alkaloids, terpenoids (oleanolic acid), and flavonoids (quercetin, } \\
\text { luteolin, apigenin, kuwanon, kaempferol) }\end{array}$ & [89] \\
\hline Oroxylum indicum & Steroids, tannins, alkaloids, glycosides, and flavonoids & [90] \\
\hline
\end{tabular}


Table 3. Cont.

Plant Name

Persicaria amplexicaulis

Phyllanthus niruri

Picrorrhiza kurroa

Picris hieracioides

Pistacia integerrima

Podophyllum hexandrum

Punica granatum

Prunus domestica

Raphanus sativus

Ricinus communis

Rosa webbiana

Rubia manjith

Saccharum officinarum

Sesamum indicum

Solanum nigrum

Solanum surattense

Taraxacum officinale

Tamarindus indica

Terminalia bellirica

Terminalia chebula

Thalictrum foliolosum
Phytochemical Constituent

Data Source

Flavonoids (quercetin), steroids ( $\beta$-sitosterol), phenolic compounds

(methyl-4-hydroxy cinnamate, gallic acid, protocatechuic acid, methyl gallate, vanicoside $A$, vanicoside $B$ ), terpenoids (arborinone), 25-hydroxycholest-5-en $3 \beta$-yl acetate

Alkaloids, terpenoids (triterpenes), phenols, flavonoids (quercetin, kaempferol), lignin glycoside, tannins, and fatty acids

Terpenoids (iridoid glycoside, triterpenoids, kutkin, picroside I $3.66 \pm 0.11 \%$, kutkoside $4.44 \pm 0.02 \%$ ), steroids, tannins, and saponins

Terpenoids (gammacer-16-ene derivatives, gammacer-16-en-3 $\beta$-yl acetate)

Phenolic acids, carotenoids, terpenoids (monoterpens 91\%, triterpenes), flavonoids (catechins), saponins, tannins, and steroids

Terpenoids, steroids, flavonoids, saponins, tannins, glycosides, and amino acids

Flavonoids, saponins, tannins, phenolic acids, glycosides, steroids (phytosterols), terpenoids, carbohydrates, and proteins

Flavonoids, phenylpropanoid esters, phenolic acids (caffeoylquinic acids), steroids, and terpenoids

Tannins (phlobatannins), saponins, flavonoids, phenolic acids (anthraquinones), steroids (phytosterol), alkaloids, terpenoids, cardiac glycosides, glucosinolates, isothiocyanates, protein $28.57 \%$, carbohydrates $39.82 \%$ and fats $27.76 \%$

Alkaloids, steroids, glycosides, flavonoids (quercetin, vitexin, rutin, kaempferol, epicatechin), terpenoids, phenolic acids (gentisic acid, ellagic acid, gallic acid, coumarins), and essential oils $37 \%$

Flavonoids, alkaloids, tannins, and saponins

Phenolic acids (quinones like glycosides, including rubiadin,1-hydroxy,2-methoxy anthraquinone, 3-dimethoxy 2 carboxy anthraquinone, munjistin, purpurin, pseudopurpurin, mollugin, furomollugin), fatty acids (rubiprasin A,B,C), ruiearbonls, and terpenoids (aborane, triterpenes)

Steroids (phytosterols), terpenoids, flavonoids, -O- and -C-glycosides, phenolic acids, fatty acid alcohols (policosanoles $2.5-80 \%$, octacosanol $50-80 \%$ of the total policosanoles)

Phenolic acids (anthraquinone) and tannins

Flavonoids (catechin, epicatechin, rutin), phenolic acids (caffeic acid, gallic acid, protocatechuic acid), fatty acids (linoleic acid $67.9 \%$ ), carbohydrates (polysaccharides), and proteins content $17 \%$

Alkaloids, tannins, saponins, phenolic acids (phenolic methyl caffeate, caffeic acid, coumarins like imperatorin, scopoletin and esculetin), steroids ( $\beta$-sitosterol),

tri-terpenoids, and other major constituents like solasonine, solamargine, solasurine, torvoside $\mathrm{K}$ and $\mathrm{L}$, khasianine, aculeatiside $\mathrm{A}$, and solamargine

Free amino acids, terpenoids (germacranolide, taraxacin, taraxacerin, a diester of taraxanthin, lactupicrin, triterpenes), carbohydrates (glucans, mannan), phenolic acids (scopoletin, esculetin), steroids (phytosterols, taraxasterol, homotaraxasterol), eudesmanolic-tetrahydroridentin B, eudesmanolide-d-glucopyranoside, and proteins

Fatty acids (n-heptadecanoate $13.00 \%$, n-octadecanoic $6.1 \%$, methyl-n-pentacosanoic $4.45 \%$, nonanoic acid $1.92 \%$, nonadecanoic acid $9.2 \%, 10$-octadecenoicacid $7.8 \%$, heptadecanoate $3.3 \%$, n-pentacosenoic acid $2.54 \%$, hexacoseoic acid $0.7 \%$ ) and proteins $7.5-6.6 \%$

Fatty acids (stearic acid $14.93 \%$, myristic acid $17.70 \%$, palmitic acid $21.6 \%$, oleic acid $45.67 \%$ ), proteins, carbohydrates, steroids ( $\beta$-sitosterol), tannins (chebulanic acid, galloyl glucose), phenolic acids (gallic, ellagic acid, ethyl gallate), alkaloids,

flavonoids, saponins, and terpenoids

Tannins (chebulic acid, chebulagic acid, corilagin), phenolic acids (gallic acid, ellagic acid), steroids ( $\beta$-sitosterol), terpenoids (triterpenes), and flavonoids (flavonol glycosides)

Alkaloids (berberine, jatrorrhizine, palmatine, thalrugosidine, thalrugosaminine, thalisopine thaligosine, thalirugidine, trhalirugine, 8-oxyberberine, berlambine, noroxyhydrastinine, $\mathrm{N}, \mathrm{O}, \mathrm{O}$-trimethylsparsiflorine, thalicarpine, thalidasine, thalfoliolosumines $\mathrm{A}$, and thalfoliolosumines $\mathrm{B}$ ) 
Table 3. Cont.

\begin{tabular}{|c|c|c|}
\hline Plant Name & Phytochemical Constituent & Data Source \\
\hline Tinospora cordifolia & Phenolic acids, flavonoids, glycosides, saponins, and alkaloids & [111] \\
\hline Trigonella emodi Ben & $\begin{array}{l}\text { Flavonoids (quercetin, luteolin, vitexin, orientin, isoorientin, vicenin-1, vicenin-2, } \\
\text { naringenin, kaempferol, } 7,4^{\prime} \text {-dimethoxyflavanone), protein, and carbohydrates }\end{array}$ & [112] \\
\hline Urtica dioica & $\begin{array}{c}\text { Alkaloids (betaine, choline), amino acids, carbohydrates, protein polymer (neutral } \\
\text { and acidic), carotenoids (carotenes), and saponins }\end{array}$ & [31] \\
\hline Vernonia anthelmintica & Fatty acids (vernolic acid) and terpenoids (vernodalin, vernodalol) & [113] \\
\hline Viola serpens & $\begin{array}{l}\text { Tannins, amino acids, reducing sugars, flavonoids (rutin), organic ester (methyl } \\
\text { salicylate), glycosides (quercitrin), alkaloids (violin), terpenoids (monoterpens, } \\
\text { sesquiterpenes), saponin, bis (2-ethylhexyl) maleate } 15.62 \% \text {, } \\
\text { 2,4,4,6-tetramethyl-2-heptene } 11.52 \% \text {, hexen-3-ol } 6.56 \% \text { and cis verbeno } 14.77 \%\end{array}$ & {$[114,115]$} \\
\hline Woodfordia fruticosa & $\begin{array}{l}\text { Phenolic acids, tannins (hydrolyzable tannins, such as woodfordins A, B, C), } \\
\text { flavonoids (quercetin glycosides, naringenin 7-glucoside, kaempferol } \\
\text { 3-O-glucoside), fatty acid alcohols (octacosanol), steroids ( } \beta \text {-sitosterol, hecogenin), } \\
\text { and terpenoids (lupeol, betulin, ursolic acid, oleanolic acid) }\end{array}$ & [116] \\
\hline
\end{tabular}

Ethnomedicinal documentation combined with the screening of various biological properties of plants is one of the convincing ways of discovering new drugs against drugresistant pathogens in the modern era or against the diseases related to oxidative stress, including jaundice. The effectiveness of these phytochemicals used in treating jaundice and other diseases has been seen in their biological activities, such as antimicrobial, antibacterial, antitumor, antiviral, or antioxidant activity. The oxidative stress of free radicals is directly associated with the presence of pathogenic organisms or due to disease-causing mechanisms of different ailments like cancer, diabetes, and inflammatory diseases [117].

\subsection{Ethnopharmacological Evidence of Some Plant Species Used for the Treatment of Jaundice}

As described in Table 3, the beneficial effects of medicinal plants are due to the presence of different bioactive compounds that are responsible for the treatment of jaundice. Ethnomedicinal studies combined with phytochemicals are one of the convincing approaches for ethnopharmacological studies [118]. The medicinal effect of different plant parts shows various hepatoprotective activities, including the curing of various liver diseases in which one of the major diseases is jaundice. Various ethnomedicinal plants are traditionally used for the treatment of jaundice, while some plants promote the discovery of active compounds, which further aids in the development of synthetic drugs against jaundice. Although some epidemiological studies are required for the practical implementation of the plants for jaundice treatment [47]. To assess the ethnomedicinal significance of the hepatoprotective plants used, particularly for treating jaundice, different plant species have been reported to be used in various in vivo experiments (Table 4). Table 4 includes various plant species, plant parts used/extracts taken, toxicant and its dose, experimental model (the animal model used for study), constituents that may be responsible for hepatoprotective activities, and their effectiveness against jaundice [15].

In vivo experimental studies with these plants (Table 4) have shown effective results in the treatment of jaundice and confer scientific evidence regarding plant use in the same. In most of the in vivo studies, hepatotoxicity is introduced with $\mathrm{CCl}_{4}$ or with paracetamol; however, in few cases, gentamycin, thioacetamide, t-BHP, and ethanol are also used for the same. Phytochemicals observed for curing hepatotoxicity are phenolic and flavonoid compounds as a major factor in curing hepatotoxicity in most of the in vivo studies. In some cases, hepatotoxicity is reduced by the decrease in serum bilirubin level and an increase in the antioxidant defense system. 
Table 4. In vivo evidence of ethnomedicinal plants used for the treatment of jaundice/hepatoprotective activity.

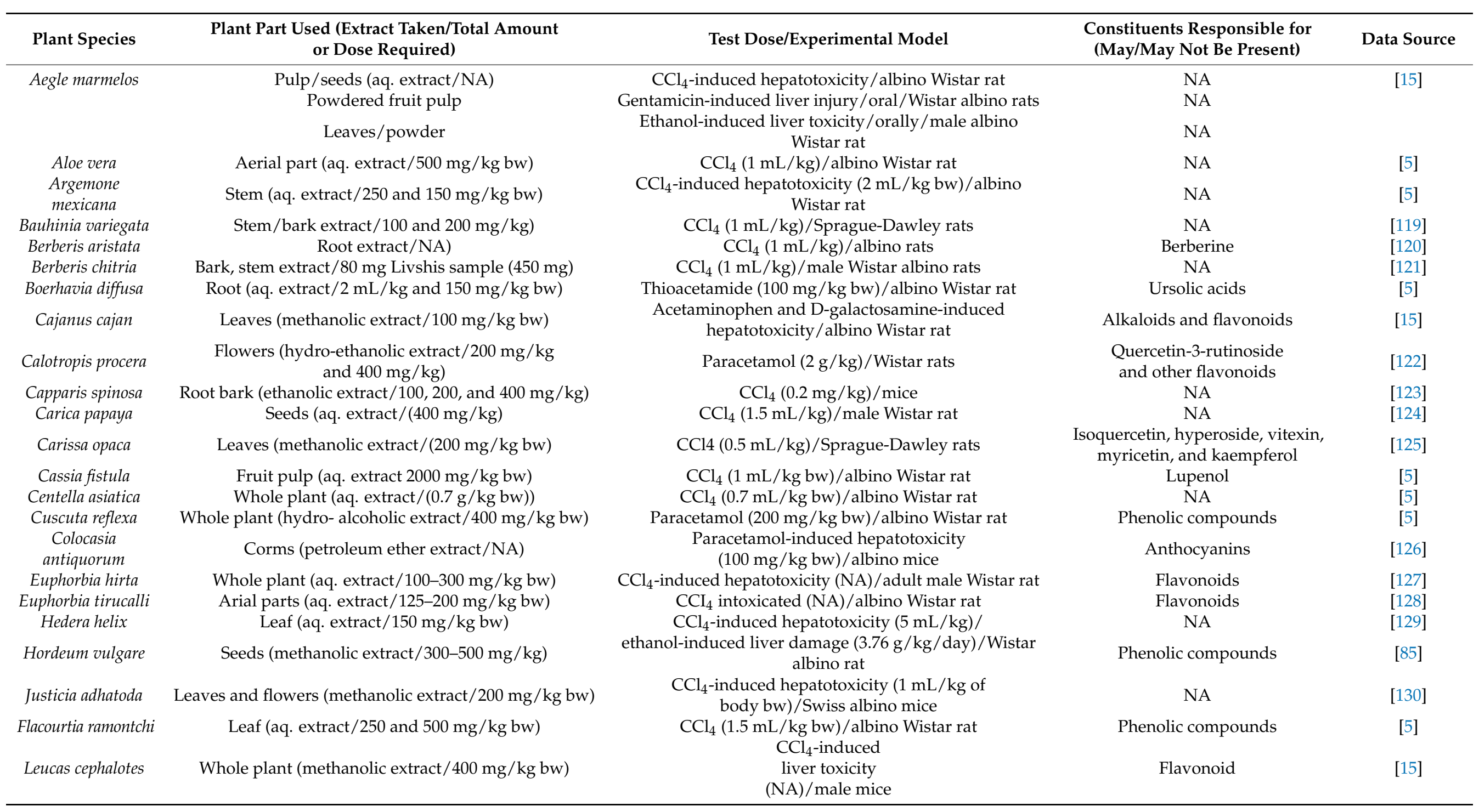


Table 4. Cont.

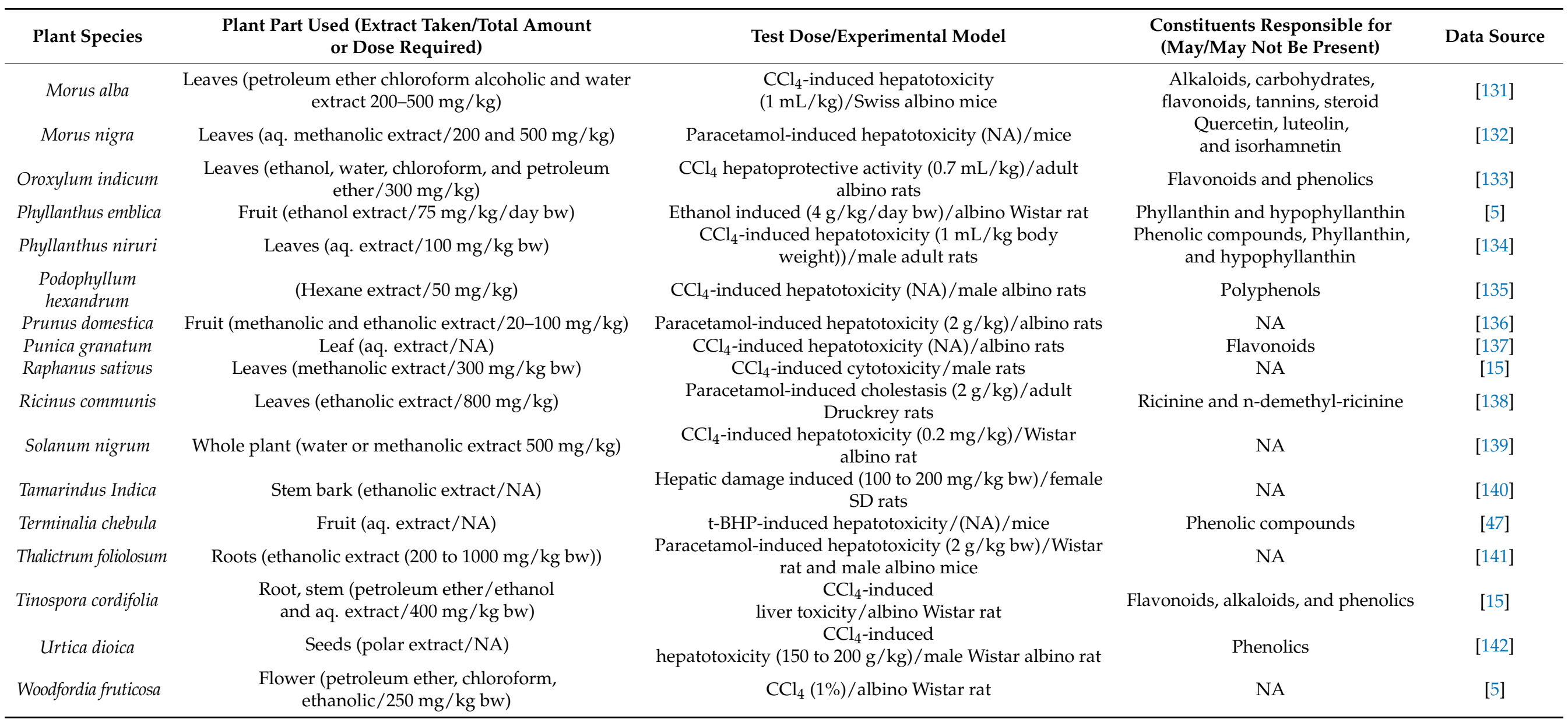


As few plants are evaluated with their experimental studies, so this study needs to be intensified more on those plant extracts, which are used extensively for jaundice treatment. Further, nano-formulation of plant extracts enhances their medicinal significance [143,144], so nano-formulation of herbal plants can also be used as an alternative for curing jaundice in the future. At the same time, farmers should be encouraged for the commercial production of important medicinal plants and should further have support from industry and government.

\section{Conclusions}

Ethnomedicinal knowledge is respected by rural people and has been shown to be useful in the treatment of various diseases and the production of medicines in the Western Himalaya from time to time. Traditional or folk-based plant medicines have shown great potential to form the basis of jaundice-curing drugs. The purpose of the present study was to record the ethnomedicinal knowledge of plants used for the treatment of jaundice by the rural and tribal communities of Himachal Pradesh in western Himalaya. The other aims of this research were to discuss the different important phytochemicals and active compounds present in these plants and to discuss the different in vivo studies performed in support of their medicinal uses, with specific reference to the treatment of jaundice. The outcome of this research showed that the rural people of Himachal Pradesh used 87 different plant species with 51 different families to treat jaundice and contribute to healthcare. These plants demonstrated the presence of several phytochemicals in them and displayed phenolic and flavonoid compounds with hepatoprotective properties in most of the experimental studies (in vivo) performed with these plants. With antioxidant potential, the phenolic and flavonoid compounds are recognized, and due to this property, these plants have been shown to be important in curing jaundice. Aloe vera, Bauhinia variegata, Berberis aristata, Emblica officinalis, and Terminalia chebula are some of these herbs, which suggest the ethnopharmacological approach to treating jaundice with the hepatoprotective operation.

There is a lot of knowledge in the latest literature on the use of various plants for treating jaundice. Nevertheless, very few studies are carried out on the scientific validation of medicinal plants by means of biochemical, clinical, and pharmacological screening to validate the jaundice healing folklore medicine. In the future, it is, therefore, very important to pursue steps that do not deviate from shifting the view of tribal people toward their indigenous belief in the treatment of jaundice to develop successful drugs or to discover new potential sources of drugs. In addition, nano-formulation of plant extracts also improves their therapeutic significance $[143,144]$, and it is also possible to use nano-formulation of herbal plants as an alternative and refining conventional knowledge for the potential cure of jaundice.

Author Contributions: D.R., R.D. and A.S. wrote the first draft of the manuscript. R.D. and H.K. contributed to making the figures and providing the literature. R.V., D.K., M.V., K.K. and S.P. revised and improved the first draft. All authors have seen and agreed on the final submitted version of the manuscript.

Funding: It was supported by the UHK project VT2019-2021. This study was also partially supported by grants from the Ministry of Health of the Czech Republic (FN HK 00179906) and the Charles University in Prague, Czech Republic (PROGRES Q40).

Conflicts of Interest: The authors declare no conflict of interest.

\section{References}

1. Thakur, K.; Bassi, K.; Sood, K. Textbook of Ethnobotany; S. Dinesh \& Co.: Jalandhar, India, 2015; pp. 1-70.

2. Aswal, B.S.; Mehrotra, B.N. Flora of Lahaul-Spiti; Bishen Singh Mahendra Pal Singh: Dehradun, India, $1994 ;$ pp. $10-15$.

3. Joshi, K.L. Geography of Himachal Pradesh; National Book Trust: New Delhi, India, 1987; pp. 220-222.

4. Abu-Rabia, A. Urinary diseases and ethnobotany among pastoral nomads in the Middle East. J. Ethnobiol. 2005, 1, 1-3.

5. Sharma, J.; Gairola, S.; Gaur, R.D.; Painuli, R.M. The treatment of jaundice with medicinal plants in indigenous communities of the sub-Himalayan region of Uttarakhand, India. J. Ethnopharmacol. 2012, 143, 262-291. [CrossRef] [PubMed] 
6. Negi, P.S.; Subramani, S.P. Ethnobotanical study in the village Chhitkul of Sangla valley, district Kinnaur, Himachal Pradesh. J. Non-Timber For. Prod. 2002, 9, 113-120.

7. Birhane, E.; Aynekulu, E.; Mekuria, W.; Endale, D. Management, use and ecology of medicinal plants in the degraded dry lands of Tigray, Northern Ethiopia. J. Med. Plants Res. 2011, 5, 308-319.

8. Mesfin, K.; Tekle, G.; Tesfay, T. Ethnobotanical study of traditional medicinal plants used by indigenous people of Gemad district, Northern Ethiopia. J. Med. Plants 2013, 1, 32-37.

9. Suriyavathana, M.; Jeevitha, M.; Aranganathan, J. In vitro antioxidant profile of Justicia tranquebariensis. Int. J. Pharm. Sci. 2011, 4, 4259-4261.

10. Yadav, R.S.; Agarwala, M. Phytochemical analysis of some medicinal plants. J. Phytol. 2011, 3, 10-14.

11. Chauhan, N.S. Important medicinal and aromatic plants of Himachal Pradesh. Indian For. 2003, 129, 979-998.

12. Verma, R.; Parkash, V.; Kumar, D. Ethno-medicinal uses of some plants of Kanag hill in Shimla, Himachal Pradesh, India. Int. J. Res. Ayurveda Pharm. 2012, 3, 319-322.

13. Baqar, S.R. Text Book of Economic Botany; Ferozsons Ltd.: Rawalpindi, Pakistan, 2001; pp. 23-100.

14. Abbasi, A.M.; Khan, M.A.; Ahmad, M.; Zafar, M.; Khan, H.; Muhammad, N.; Sultana, S. Medicinal plants used for the treatment of jaundice and hepatitis based on socio-economic documentation. Afr. J. Biotechnol. 2009, 8, 1644-1650.

15. Janghel, V.; Patel, P.; Chandel, S.S. Plants used for the treatment of icterus (jaundice) in central India: A review. Ann. Hepatol. 2019, 18, 658-672. [CrossRef]

16. Riva, M.A.; Riva, E.; Spicci, M.; Strazzabosco, M.; Giovannini, M.; Cesana, G. "The city of Hepar": Rituals, gastronomy, and politics at the origins of the modern names for the liver. J. Hepatol. 2011, 55, 1132-1136. [CrossRef]

17. Gao, B.; Bataller, R. Alcoholic liver disease: Pathogenesis and new therapeutic targets. Gastroenterology 2011, 141, 1572-1585. [CrossRef] [PubMed]

18. Rahim, Z.B.; Rahman, M.M.; Saha, D.; Hosen, S.Z.; Paul, S.; Kader, S. Ethnomedicinal plants used against jaundice in Bangladesh and its economical prospects. Bull. Pharma. Res. 2012, 2, 91-105.

19. Feldman, A.G.; Sokol, R.J. Neonatal cholestasis. Neoreviews 2013, 14, e63-e73. [CrossRef] [PubMed]

20. Sarkhel, S. Ethnomedicinal uses of some plants in treatment of jaundice by tribal communities of Paschim Medinipur district, West Bengal, India. Open Access J. Med. Arom. Plants. 2015, 6, 43-48.

21. Poduri, C.D. Jaundice: A brief historical perspective. Ann. Intern. Med. 2016, 13, 76-79. [CrossRef]

22. Ebrahimimd, S.; Ashkani-Esfahani, S.; Poormahmudibs, A. Investigating the efficacy of Zizyphus jujuba on neonatal jaundice. Iran J. Pediatr. 2011, 21, 320-324.

23. Kumar, S.; Paul, R. Ethnomedicinal plants used for jaundice in Kangra district (Himachal Pradesh). J. Plant Dev. Sci. 2009, 1, 35-39.

24. Kumar, N.; Choyal, R. Traditional use of some plants of Hamirpur district of Himachal Pradesh for the treatment of jaundice, hepatitis and other liver disorders. Int. J. Theor. Appl. Sci. 2012, 4, 201-205.

25. Bharadwaj, J.; Seth, M.K. Medicinal plant resources of Bilaspur, Hamirpur and Una districts of Himachal Pradesh: An ethnobotanical enumeration. J. Med. Plants Stud. 2017, 5, 99-110.

26. Thakur, M.; Asrani, R.K.; Thakur, S.; Sharma, P.K.; Patil, R.D.; Lal, B.; Parkash, O. Observations on traditional usage of ethnomedicinal plants in humans and animals of Kangra and Chamba districts of Himachal Pradesh in north-western Himalaya, India. J. Ethnopharmacol. 2016, 191, 280-300. [CrossRef]

27. Singh, J.; Singh, J.; Sharma, D. Traditional wisdom to treat the most common ailments in Chopal region of Shimla District, Himachal Pradesh, India. Plant Arch. 2018, 18, 2759-2769.

28. Kala, C.P. Medicinal plants of the high-altitude cold desert in India: Diversity, distribution and traditional uses. Int. J. Biodivers. Sci. Ecosyst. Serv. Manag. 2006, 2, 43-56. [CrossRef]

29. Kaur, M.; Singhal, V.K.; Singh, J. Use of some ethnomedicinal herbs by the natives of Solang Valley, Kullu District, Himachal Pradesh. Int. J. Pharm. Sci. 2017, 9, 222-227. [CrossRef]

30. Sekar, K.C.; Srivastava, S.K. Traditional uses of plants in curing jaundice in the Pin Valley National Park, Himachal Pradesh. Indian J. Tradit. Know. 2005, 4, 314-316.

31. Singh, K.N.; Lal, B. Ethnomedicines used against four common ailments by the tribal communities of Lahaul-Spiti in western Himalaya. J. Ethnopharmacol. 2008, 115, 147-159. [CrossRef] [PubMed]

32. Rani, S.; Rana, J.C.; Rana, P.K. Ethnomedicinal plants of Chamba district, Himachal Pradesh, India. J. Med. Plants Res. 2013, 7, 3147-3157.

33. Kaur, I.; Sharma, S.; Lal, S. Ethnobotanical survey of medicinal plants used for different diseases in Mandi district, Himachal Pradesh. Int. J. Res. Pharm. Chem. 2011, 1, 1167-1171.

34. Rani, S.; Rana, J.C.; Jeelani, S.M.; Gupta, R.C.; Kumari, S. Ethnobotanical notes on 30 medicinal polypetalous plants of district Kangra of Himachal Pradesh. J. Med. Plants Res. 2013, 7, 1362-1369.

35. Thakur, S. Medicinal plants used by tribal inhabitants of Sirmour district, Himachal Pradesh. Indian J. Sci. Res. 2011, 2, 125-127.

36. Verma, S.; Chauhan, N.S. Indigenous medicinal plants knowledge of Kunihar forest division, district Solan. J. Tradit. Know. 2007, 6, 494-497.

37. Kumar, G.; Kumar, V.; Thakur, K. Some overlooked Ethno-medicinal plants of district Bilaspur, Himachal Pradesh (India). CPUH Res. J. 2018, 3, 116-123. 
38. Singh, K.J.; Thakur, A.K. Medicinal plants of the Shimla hills, Himachal Pradesh: A survey. Int. J. Herbal Med. $2014,2,118-127$.

39. Chand, R.; Kaur, R.; Kaur, A.; Kumar, V.; Nirmala, C.; Singh, A.N. Assessment of ethnomedicinal plant diversity of Una and Hamirpur district of Himachal Pradesh, India: An ethno-ecological approach. Ann. Plant Sci. 2016, 5, 1475-1490. [CrossRef]

40. Rani, S.; Rana, J.C. Ethnobotanical uses of some plants of Bhattiyat block in district Chamba, Himachal Pradesh (Western Himalaya). Ethnobot. Res. Appl. 2014, 12, 407-414. [CrossRef]

41. Boktapa, N.R.; Sharma, A.K. Wild medicinal plants used by local communities of Manali, Himachal Pradesh, India. Ethnobot. Leaflets. 2010, 4, 259-267.

42. Rana, M.S.; Samant, S.S. Diversity, indigenous uses and conservation status of medicinal plants in Manali wildlife sanctuary, North western Himalaya. J. Tradit. Know. 2011, 10, 439-459.

43. Rahman, A.M. Ethno-medicinal practices for the treatment of asthma, diuretic, jaundice, piles, rheumatism and vomiting at the village Abdullahpur under Akkelpur Upazilla of Joypurhat district, Bangladesh. J. Eng. Appl. Sci. 2014, 1, 4-8.

44. Amiri, M.S.; Jabbarzadeh, P.; Akhondi, M. An ethnobotanical survey of medicinal plants used by indigenous people in Zangelanlo district, Northeast Iran. J. Med. Plants Res. 2012, 6, 749-753.

45. Edeoga, H.O.; Okwu, D.E.; Mbaebie, B.O. Phytochemical constituents of some Nigerian medicinal plants. Afr. J. Biotechnol. 2005, 4, 685-688. [CrossRef]

46. Njoku, V.O.; Obi, C.; Onyema, O.M. Phytochemical constituents of some selected medicinal plants. Afr. J. Biotechnol. 2011, 10, 15020-15024. [CrossRef]

47. Tewari, D.; Mocan, A.; Parvanov, E.D.; Sah, A.N.; Nabavi, S.M.; Huminiecki, L.; Atanasov, A.G. Ethnopharmacological approaches for therapy of jaundice: Part II. Highly used plant species from Acanthaceae, Euphorbiaceae, Asteraceae, Combretaceae, and Fabaceae families. Front. Pharmacol. 2017, 8, 519. [CrossRef] [PubMed]

48. Nascimento, G.G.; Locatelli, J.; Freitas, P.C.; Silva, G.L. Antibacterial activity of plant extracts and phytochemicals on antibioticresistant bacteria. Braz. J. Microbiol. 2000, 31, 247-256. [CrossRef]

49. Bhat, V.S.; Nasavatl, D.D.; Mardikar, B.R. Adhatoda vasica-an ayurvedic medicinal plant. Drug Dev. Res. 1978, 15, 6-10.

50. Pathak, R.R. Therapeutic Guide to Ayurvedic Medicine: A Hand Book of Ayurvedic Medicine; Shree Baidyanath Ayurved Bhawan Pvt. Ltd.: Patna, India, 1970; pp. 25-330.

51. Irshad, A.H.; Pervaiz, A.H.; Abrar, Y.B.; Fahelboum, I.; Awen, B.Z. Antibacterial activity of Berberis lycium root extract. Trakia J. Sci. 2013, 1, 88-90.

52. Pei-Gen, X.I.A.O.; Feng-Peng, W.A.N.G.; Feng, G.A.O.; Lu-Ping, Y.A.N.; Dong-Lin, C.H.E.N.; Yong, L.I. A pharmacophylogenetic study of Aconitum L. (Ranunculaceae) from China. J. Syst. Evol. 2005, 44, 1-46.

53. Ranjan, V.; Vats, M.; Gupta, N.; Sardana, S. Antidiabetic potential of whole plant of Adiantum capillus veneris linn. in streptozotocin induced diabetic rats. Int. J. Curr. Pharm. Res. 2014, 6, 341-347.

54. Ruhil, S.; Balhara, M.; Dhankhar, S.; Chhillar, A.K. Aegle marmelos (Linn.) Correa: A potential source of phytomedicines. J. Med. Plant Res. 2011, 5, 1497-1507.

55. Mathela, C.S.; Padalia, R.C.; Joshi, R.K. Variability in fragrance constituents of Himalayan Tanacetum species: Commercial potential. J. Essent. Oil Bear. Plants 2008, 5, 503-513. [CrossRef]

56. Lakshmi, P.T.V.; Rajalakshmi, P. Identification of phyto components and its biological activities of aloe vera through the gas chromatography-mass spectrometry. J. Pharm. Res. 2011, 2, 247-249.

57. Brahmachari, G.; Gorai, D.; Roy, R. Argemone mexicana: Chemical and pharmacological aspects. Rev. Bras. Farmacogn. 2013, 23, 559-567. [CrossRef]

58. Mushtaq, S.; Aga, M.A.; Qazi, P.H.; Ali, M.N.; Shah, A.M.; Lone, S.; Hussain, A.; Shah, Z.H. Isolation, characterization and HPLC quantification of compounds from Aquilegia fragrans Benth: Their in vitro antibacterial activities against bovine mastitis pathogens. J. Ethnopharmacol. 2016, 178, 9-12. [CrossRef] [PubMed]

59. Bhardwaj, D.; Kaushik, N. Phytochemical and pharmacological studies in genus Berberis. Phytochem. Rev. 2012, 11, 523-542. [CrossRef]

60. Joshi, H.; Saxena, G.K.; Singh, V.; Arya, E.; Singh, R.P. Phytochemical investigation, isolation and characterization of betulin from bark of Betula utilis. Res. J. Pharmacogn. Phytochem. 2013, 2, 145-151.

61. Mishra, S.; Aeri, V.; Gaur, P.K.; Jachak, S.M. Phytochemical, therapeutic, and ethnopharmacological overview for a traditionally important herb: Boerhavia diffusa Linn. Biomed. Res. Int. 2014, 2014, 808302. [CrossRef]

62. Karthikairaj, K.; Sevarkodiyone, S.P.; Pavaraj, M.; Balaji, S.; Senthikumar, P.; Kalaivani, A. Effect of organic amendments on the level of chemical constituents of redgram, Cajanus cajan infected with root-knot nematode, Meloidogyne javanica. Middle East J. Sci. Res. 2012, 12, 1068-1071.

63. Al-Snafi, A.E. The chemical constituents and pharmacological effects of Capsella bursa-pastoris-a review. Int. J. Pharmacol. Toxicol. 2015, 5, 76-81.

64. Sunil, P.; Sanjay, Y.; Vinod, S. Pharmacognostical investigation and standardization of capsicum annum L. roots. Int. J. Pharmacogn. 2012, 4, 21-24.

65. Alorkpa, E.J.; Boadi, N.O.; Badu, M.; Saah, S.A. Phytochemical screening, antimicrobial and antioxidant properties of assorted Carica papaya leaves in Ghana. J. Med. Plant Res. 2016, 4, 193-198.

66. Izhar, S.; Ahmed, D. Carissa opaca: A plant with great potential for future drugs for degenerative and infectious diseases. Chem. Select. 2016, 1, 3005-3011. [CrossRef] 
67. Sekar, T.; Arumugam, T.; Ayyanar, M.; Pillai, J. Phytochemical screening and antibacterial activity of leaf and callus extracts of Centella asiatica. Bangladesh J. Pharmacol. 2011, 6, 55-60. [CrossRef]

68. Arora, M.; Singh, S.; Kaur, P. Pharmacognostic and phytochemical evaluation of selected seeds of 'Cicer arietinum'Linn. seeds from Roopnagar, Punab. Int. J. Pharm. Sci. Invent. 2013, 2, 18-29.

69. Prajapati, R.; Kalariya, M.; Umbarkar, R.; Parmar, S.; Sheth, N. Colocasia esculenta: A potent indigenous plant. Int. J. Nutr. Pharmacol. 2011, 1, 90-96. [CrossRef]

70. Xiao, L.G.; Zhang, S.C.; Zhang, Y.; Liu, L.; Zhang, H.L.; Yu, Q.; An, L.K. Sesquiterpenoids from the aerial parts of Conyza japonica and their inhibitory activity against the nitric oxide production. Fitoterapia 2020, 142, 104473. [CrossRef] [PubMed]

71. Zhang, Y.; Zhang, W.; Zhang, J.; Chen, S.; Lin, X. Chemical constituents of Crepis flexuosa. Chin. J. Appl. Environ. Biol. 2011, 4, 509-511.

72. Ahmad, A.; Tandon, S.; Xuan, T.D.; Nooreen, Z. A review on phytoconstituents and biological activities of Cuscuta species. Biomed. Pharmacother. 2017, 92, 772-795. [CrossRef]

73. Das, J.; Chowdhury, A.; Biswas, K.; Karmakar, K.U.; Sharif, R.S.; Raihan, Z.S.; Muhit, A.M. Cytotoxicity and antifungal activities of ethanolic and chloroform extracts of Cucumis sativus Linn (Cucurbitaceae) leaves and stems. Res. J. Phytochem. 2012, 6, 25-30.

74. Soni, P.; Siddiqui, A.A.; Dwivedi, J.; Soni, V. Pharmacological properties of Datura stramonium L. as a potential medicinal tree: An overview. Asian Pac. J. Trop. Biomed. 2012, 2, 1002-1008. [CrossRef]

75. Variya, C.B.; Bakrania, K.; Patel, S.S. Emblica officinalis (Amla): A review for its phytochemistry, ethnomedicinal uses and medicinal potentials with respect to molecular mechanisms. Pharmacol. Res. 2016, 1, 180-200. [CrossRef]

76. Li, E.T.; Liu, K.H.; Zang, M.H.; Zhang, X.L.; Jiang, H.Q.; Zhou, H.L.; Wu, Y. Chemical constituents from Euphorbia hirta. Biochem. Syst. Ecol. 2015, 62, 204-207. [CrossRef]

77. Yamamoto, Y.; Mizuguchi, R.; Yamada, Y. Chemical constituents of cultured cells of Euphorbia tirucalli and E. millii. Plant Cell Rep. 1981, 1, 29-30. [CrossRef] [PubMed]

78. Al-Snafi, A.E. The pharmacology of Equisetum arvense-A review. IOSR J. Pharm. 2017, 7, 31-42. [CrossRef]

79. Lalsare, S.; Verma, P.K.; Khatak, M.; Ranjan, S.; Rajurakar, S.; Gurav, S.S. Anti-inflammatory and antimicrobial activity of Flacourtia ramontchi leaves. Drug Dev. Res. 2011, 3, 308-313.

80. Ismail, M.; Hussain, J.; Khan, A.U.; Khan, A.L.; Ali, L.; Khan, F.U.; Khan, Z.A.; Niaz, U.; Lee, I.J. Antibacterial, antifungal, cytotoxic, phytotoxic, insecticidal, and enzyme inhibitory activities of Geranium wallichianum. Evid. Based Complement. Altern. Med. 2012, 2012, 305906. [CrossRef] [PubMed]

81. Shabir, M.; Agnihotri, P.; Husain, D.; Tiwari, J.K.; Husain, T. On the current status of the genus Gentiana L. (Gentianaceae) in India. Pleione 2017, 11, 16-24.

82. Painuly, P.; Varma, N.; Tandon, J.S. Constituents of Geum elatum. J. Nat. Prod. 1984, 47, 181-189. [CrossRef]

83. Al-Snafi, A.E. Pharmacological and therapeutic activities of Hedera helix-a review. IOSR J. Pharm. 2018, 8, 41-53.

84. Kapoor, D.N.; Singh, G.; Kaur, T. A review on pharmacognostic, phytochemical and pharmacological data of various species of Hippophae (Sea buckthorn). Int. J. Green Pharm. 2017, 11, S62-S74.

85. Shah, P.A.; Parmar, M.Y.; Thakkar, V.T.; Gandhi, T.R. Hepatoprotective activity of Hordeum vulgare Linn. seeds against ethanolinduced liver damage in rats. Int. J. Green Pharm. 2009, 3, 38-43.

86. Singh, T.; Singh, O.; Singh, H. Adhatoda vasica Nees: Phytochemical and pharmacological profile. J. Nat. Prod. 2011, 1, 29-39. [CrossRef]

87. Naidu, J.R.; Ismail, R.B.; Yeng, C.; Sasidharan, S.; Kumar, P. Chemical composition and antioxidant activity of the crude methanolic extracts of Mentha spicata. J. Phytol. 2012, 4, 13-18.

88. Yang, Y.; Yang, X.; Xu, B.; Zeng, G.; Tan, J.; He, X.; Zhou, Y. Chemical constituents of Morus alba L. and their inhibitory effect on 3T3-L1 preadipocyte proliferation and differentiation. Fitoterapia 2014, 98, 222-227. [CrossRef] [PubMed]

89. Mallhi, T.H.; Qadir, M.I.; Khan, Y.H. Determination of phytoconstituents of n-hexane extract of leaves of Morus nigra and evaluation of their effects on biochemical and histopathological parameters in paracetamol intoxicated mice liver. Braz. J. Pharm. Sci. 2018, 54, 1-9. [CrossRef]

90. Dev, L.R.; Ranjeeta, P.; Anurag, M.; Rajiv, G. Pharmacognostic and phytochemical studies of bark of Oroxylum indicum. Rev. Bras. Farmacogn. 2010, 2, 297-303. [CrossRef]

91. Sahidin, I.; Bahrun, A.; Taufik, M.; Mahatva Yodha, A.W.; Sabandar, C.W.; Imran, I.; Kadidae, L.O.; Diantini, A. Chemical constituents of Persicaria sagittata (L.) H. gross: Antioxidant activity and chemotaxonomy significance. Jundishapur J. Nat. Pharm. Prod. 2019, 15, 1-8. [CrossRef]

92. Samali, A.; Florence, D.T.; Odeniran, O.A.; Cordelia, O.N. Evaluation of chemical constituents of Phyllanthus niruri. Afr. J. Pharm. Pharmacol. 2012, 6, 125-128. [CrossRef]

93. Rathee, D.; Rathee, P.; Rathee, S.; Rathee, D. Phytochemical screening and antimicrobial activity of Picrorrhiza kurroa, an Indian traditional plant used to treat chronic diarrhoea. Arab. J. Chem. 2016, 9, 1307-1313. [CrossRef]

94. Shiojima, K.; Masuda, K.; Ooishi, Y.; Suzuki, H.; Ageta, H. Composite constituents: New migrated gammacerane triterpenoids from roots of Picris hieracioides subsp. japonica. Tetrahedron Lett. 1989, 30, 6873-6874. [CrossRef]

95. Bibi, Y.; Zia, M.; Qayyum, A. An overview of Pistacia integerrima a medicinal plant species: Ethnobotany, biological activities and phytochemistry. Pak. J. Pharm. Sci. 2015, 28, 1009-1013. 
96. Malik, M.A.; Srivastava, P.; Ahmad, S.B. Quantitative estimation of phytochemicals and antimicrobial activity of Podophyllum hexandrum. Int. J. Curr. Sci. 2018, 6, 1152-1155.

97. Moorthy, K.; Punitha, T.; Vinodhini, R.; Thippan, B.; Sureshkumar, B.T.; Vijayalakshmi, P.; Thajuddin, N. Antimicrobial activity and qualitative phytochemical analysis of Punica granatum Linn. (Pericarp). J. Med. Plants Res. 2013, 7, 474-479.

98. Poonam, V.; Raunak; Kumar, G.; Reddy, L.C.S.; Jain, R.; Sharma, S.; Prasad, A.K.; Parmar, V. Chemical constituents of the genus Prunus and their medicinal properties. Curr. Med. Chem. 2011, 18, 3758-3824. [CrossRef] [PubMed]

99. Janjua, S.; Shahid, M. Phytochemical analysis and in vitro antibacterial activity of root peel extract of Raphanus sativus L. var niger. Adv. Med. Plant Res. 2013, 1, 1-7.

100. Ribeiro, P.R.; de Castro, R.D.; Fernandez, L.G. Chemical constituents of the oilseed crop Ricinus communis and their pharmacological activities: A review. Ind. Crops Prod. 2016, 91, 358-376. [CrossRef]

101. Raj, J.; Basant, B.; Murugan, P.M.; da Silva, J.A.T.; Saurav, K.; Chaurasia, O.P.; Singh, S.B. Screening phytochemical constituents of 21 medicinal plants of trans-Himalayan region. Med. Aromat. Plant Sci. Biotechnol. 2010, 4, 90-93.

102. Verma, A.; Kumar, B.; Alam, P.; Singh, V.; Gupta, S.K. Rubia cordifolia-A review on pharmaconosy and phytochemistry. Int. J. Pharm. Sci. Res. 2016, 7, 2720-2731.

103. Singh, A.; Lal, R.U.; Mukhtar, H.; Singh, P.S.; Shah, G.; Dhawan, R.K. Phytochemical profile of sugarcane and its potential health aspects. Phoog. Rev. 2015, 9, 45-53. [CrossRef]

104. Kumar, P.S.; Patel, J.S.; Saraf, M.N. Mechanism of vasorelaxant activity of a fraction of root extract of Sesamum indicum Linn. Indian J. Exp. Biol. 2008, 46, 457-464.

105. Chauhan, R.; Ruby, K.M.; Shori, A.; Dwivedi, J. Solanum nigrum with dynamic therapeutic role: A review. Int. J. Pharm. Sci. Res. 2012, 15, 65-71.

106. Ahmed, M.M.; Andleeb, S.; Saqib, F.; Hussain, M.; Khatun, M.N.; Ahmad, B.; Rahman, H. Diuretic and serum electrolyte regulation potential of aqueous methanolic extract of Solanum surattense fruit validates its folkloric use in dysuria. BMC Complement. Altern. Med. 2016, 16, 2-8. [CrossRef] [PubMed]

107. Khanzada, S.K.; Shaikh, W.; Sofia, S.; Kazi, T.G.; Usmanghani, K.; Kabir, A.; Sheerazi, T.H. Chemical constituents of Tamarindus indica L. medicinal plant in Sindh. Pak. J. Bot. 2008, 40, 2553-2559.

108. Kumar, N.; Khurana, S.M. Phytochemistry and medicinal potential of the Terminalia bellirica Roxb. (Bahera). J. Nat. Prod. Res. 2018, 9, 97-107.

109. Upadhyay, A.; Agrahari, P.; Singh, D.K. A review on the pharmacological aspects of Terminalia chebula. Int. J. Pharmacol. 2014, 10, 289-298. [CrossRef]

110. Sharma, N.; Kumar, V.; Chopra, M.P.; Sourirajan, A.; Dev, K. Thalictrum foliolosum: A lesser unexplored medicinal herb from the himalayan region as a source of valuable phytocompounds. J. Ethnopharmacol. 2020, 255, 112736. [CrossRef] [PubMed]

111. Shervani, Z.A.; Mishra, P.K. Phytochemical study of Tinospora cordifolia grown on three different soil conditions. Res. J. Life Sci. Bioinform. Pharm. Chem. Sci. 2017, 5, 810-815.

112. Vigh, S.; Cziaky, Z.; Sinka, L.T.; Pribac, C.; Moş, L.; Turcuş, V.; Remenyik, J.; Mathe, E. Analysis of phytoconstituent profile of fenugreek-Trigonella foenuem-graecum L.-seed extracts. Studia Univ. Babes-Bolyai Chem. 2017, 62, 145-166. [CrossRef]

113. Akbar, S. Vernonia anthelmintica Willd. (Asteraceae/Compositae). In Handbook of 200 Medicinal Plants; Akbar, S., Ed.; Springer: Cham, Switzerland, 2020; pp. 1895-1899.

114. Chandra, D.; Kohli, G.; Prasad, K.; Bisht, G.; Punetha, V.D.; Khetwal, K.S.; Devrani, M.K.; Pandey, H.K. Phytochemical and ethnomedicinal uses of family Violaceae. Curr. Res. Chem. 2015, 7, 44-52. [CrossRef]

115. Chandra, D.; Kohli, G.; Prasad, K.; Bisht, G.; Punetha, V.D.; Pandey, H.K. Chemical composition of the essential oil of Viola serpens from Bageshwar (Shama), Uttarakhad, India. J. Med. Plant Res. 2017, 11, 513-517.

116. Das, P.K.; Goswami, S.; Chinniah, A.; Panda, N.; Banerjee, S.; Sahu, N.P.; Achari, B. Woodfordia fruticosa: Traditional uses and recent findings. J. Ethnopharmacol. 2007, 110, 189-199. [CrossRef]

117. Dhalaria, R.; Verma, R.; Kumar, D.; Puri, S.; Tapwal, A.; Kumar, V.; Nepovimova, E.; Kuca, K. Bioactive compounds of edible fruits with their anti-aging properties: A comprehensive review to prolong human life. Antioxidants 2020, 9, 1123. [CrossRef] [PubMed]

118. Shantabi, L.; Jagetia, G.C.; Vabeiryureilai, M.; Lalrinzuali, K. Phytochemical screening of certain medicinal plants of Mizoram, India and their folklore use. J. Biodivers. Biopros. Dev. 2014, 1, 1-9.

119. Bodakhe, S.H.; Ram, A. Hepatoprotective properties of Bauhinia variegata bark extract. Yakugaku zasshi. Farumashia 2007, 127, 1503-1507.

120. Dehar, N.A.; Walia, R.A.; Verma, R.B.; Pandey, P.I. Hepatoprotective activity of Berberis aristata root extract against chemical induced acute hepatotoxicity in rats. Asian J. Pharm. Clin. Res. 2013, 6, 53-56.

121. Bera, T.K.; Chatterjee, K.; De, D.; Ali, K.M.; Jana, K.; Maiti, S.; Ghosh, D. Hepatoprotective activity of livshis, a polyherbal formulation in CCl4-Induced hepatotoxic male Wistar rats: A toxicity screening approach. Biosciences 2011, 3, 103-110. [CrossRef]

122. Setty, S.R.; Quereshi, A.A.; Swamy, A.V.; Patil, T.; Prakash, T.; Prabhu, K.; Gouda, A.V. Hepatoprotective activity of Calotropis procera flowers against paracetamol-induced hepatic injury in rats. Fitoterapia 2007, 78, 451-455. [CrossRef]

123. Aghel, N.; Rashidi, I.; Mombeini, A. Hepatoprotective activity of Capparis spinosa root bark against CCl4 induced hepatic damage in mice. Iran J. Pharm. Res. 2007, 6, 285-290. 
124. Adeneye, A.A.; Olagunju, J.A.; Banjo, A.A.; Abdul, S.F.; Sanusi, O.A.; Sanni, O.O.; Osarodion, B.A.; Shonoiki, O.E. The aqueous seed extract of Carica papaya Linn. prevents carbon tetrachloride induced hepatotoxicity in rats. Int. J. Appl. Res. Nat. Prod. 2009, $2,19-32$.

125. Sahreen, S.; Khan, M.R.; Khan, R.A. Hepatoprotective effects of methanol extract of Carissa opaca leaves on $\mathrm{CCl}_{4}$-induced damage in rat. BMC Comp. Alt. Med. 2011, 11, 48. [CrossRef]

126. Tuse, T.A.; Harle, U.N.; Bore, V.V. Hepatoprotective activity of Colocasia antiquorum against experimentally induced liver injury in rats. Malays. J. Pharma. Sci. 2009, 7, 99-112.

127. Dubey, S.; Mehta, S. Hepatoprotective activity of Euphorbia hirta Linn. Plant against carbon tetrachloride-induced hepatic injury in rats. Food Bio. Med. Sci. 2014, 1, 108-111.

128. Jyothi, T.M.; Shankariah, M.M.; Prabhu, K.; Lakshminarasu, S.; Srinivasa, G.M.; Ramachandra, S.S. Hepatoprotective and antioxidant activity of Euphorbia tirucalli. Iran. J. Pharma. Ther. 2008, 7, 25-30.

129. Adil, A.; Khan, S.S.; Naeem, S.; Ikram, R.; Jaffer, N. Evaluation of acute and chronic hepatoprotective activity of Hedera helix L. Aqueous leaf extract on carbon tetrachloride-induced hepatotoxicity in rat model. Pak. J. Phytopathol. 2017, $34,1-15$.

130. Afzal, U.; Gulfraz, M.; Hussain, S.; Malik, F.; Maqsood, S.; Shah, I.; Mahmood, S. Hepatoprotective effects of Justicia adhatoda L. against carbon tetrachloride (CCl4) induced liver injury in Swiss albino mice. Afr. J. Pharm. Pharmacogn. 2013, 7, 8-14. [CrossRef]

131. Hogade, M.G.; Patil, K.S.; Wadkar, G.H.; Mathapati, S.S.; Dhumal, P.B. Hepatoprotective activity of Morus alba (Linn.) leaves extract against carbon tetrachloride induced hepatotoxicity in rats. Afr. J. Pharma. Pharmacogn. 2010, 4, 731-734.

132. Mallhi, T.H.; Qadir, M.I.; Khan, Y.H.; Ali, M. Hepatoprotective activity of aqueous methanolic extract of Morus nigra against paracetamol-induced hepatotoxicity in mice. Bangladesh J. Pharmacol. 2014, 9, 60-66. [CrossRef]

133. Tenpe, C.R.; Upaganlawar, A.; Burle, S.; Yeole, Y.G. In vitro antioxidant and preliminary hepatoprotective activity of Oroxylum indicum Vent leaf extracts. Pharmacologyonline 2009, 1, 35-43.

134. Harish, R.; Shivanandappa, T. Antioxidant activity and hepatoprotective potential of Phyllanthus niruri. Food Chem. 2006, 95, 180-185. [CrossRef]

135. Ganie, S.A.; Zargar, B.A.; Masood, A.; Zargar, M.A. Hepatoprotective and antioxidant activity of rhizome of Podophyllum hexandrum against carbon tetra chloride induced hepatotoxicity in rats. Biomedicine 2013, 26, 209-221. [CrossRef]

136. Soni, M.; Tanwar, Y.S. Hepatoprotective activity of Prunus domestica fruit extract against paracetamol-induced liver damage in Albino rats. J. Crit. Rev. 2020, 7, 4729-4734.

137. Kumar, M.; Dandapat, S.; Sinha, M.P. Hepatoprotective activity of Punica granatum leaf extract against carbon tetrachloride induced hepatotoxicity in rats. Balneo 2018, 9, 24-27. [CrossRef]

138. Visen, P.S.; Shukla, B.; Patnaik, G.K.; Tripathi, S.C.; Kulshreshtha, D.K.; Srimal, R.C.; Dhawan, B.N. Hepatoprotective activity of Ricinus communis leaves. Int. J. Pharmacogn. 1992, 30, 241-250. [CrossRef]

139. Elhag, R.A.M.; El Badwi, S.M.A.; Bakhiet, A.O.; Galal, M. Hepatoprotective activity of Solanum nigrum extracts on chemically induced liver damage in rats. J. Vet. Med. Anim. Health 2011, 3, 45-50.

140. Meena, S.Z.; Rahman, M.A.; Bagga, P.; Mujahid, M. Hepatoprotective activity of Tamarindus indica Linn stem bark ethanolic extract against hepatic damage induced by co-administration of antitubercular drugs isoniazid and rifampicin in Sprague Dawley rats. J. Basic Clin. Physiol. Pharmacol. 2018, 30, 131-137. [CrossRef] [PubMed]

141. Marslin, G.; Prakash, J. Hepatoprotective Activity of Thalictrum foliolosum (Ranunculaceae) Root Ethanolic extract. Int. J. Life Sci. Pharma. Res. 2020, 10, 8-11.

142. Kanter, M.; Coskun, O.; Budancamanak, M. Hepatoprotective effects of Nigella sativa L and Urtica dioica L on lipid peroxidation, antioxidant enzyme systems and liver enzymes in carbon tetrachloride-treated rats. World J. Gastroenterol. 2005, 11, $6684-6688$. [CrossRef]

143. Kumar, H.; Bhardwaj, K.; Dhanjal, D.S.; Nepovimova, E.; Sen, F.; Regassa, H.; Singh, R.; Verma, R.; Kumar, V.; Kumar, D.; et al. Fruit extract mediated green synthesis of metallic nanoparticles: A new avenue in pomology applications. Int. J. Mol. Sci. 2020, 21, 8458. [CrossRef]

144. Kumar, H.; Bhardwaj, K.; Kuca, K.; Kalia, A.; Nepovimova, E.; Verma, R.; Kumar, D. Flower-Based green synthesis of metallic nanoparticles: Applications beyond fragrance. Nanomaterials 2020, 10, 766. [CrossRef] 